\title{
The Rise and Fall of Brazilian Inequality: 1981-2004
}

\author{
Francisco H.G. Ferreira ${ }^{1}$, Phillippe G. Leite ${ }^{2}$ and Julie A. Litchfield ${ }^{3}$ \\ ${ }^{1}$ Research Department, The World Bank \\ ${ }^{2} \mathrm{PhD}$ student at EHESS, Campus Paris-Jourdan \\ ${ }^{3}$ Poverty Research Unit, University of Sussex
}

Keywords: Brazil; Income Distribution; Inequality; Poverty. JEL Classification: D31, I32, N36, O15.

\begin{abstract}
Measured by the Gini coefficient, income inequality in Brazil rose from 0.57 in 1981 to 0.63 in 1989, before falling back to 0.56 in 2004. This latest figure would lower Brazil's world inequality rank from 2nd (in 1989) to 10th (in 2004). Poverty incidence also followed an inverted U-curve over the last quarter century, rising from 0.30 in 1981 to 0.33 in 1993, before falling to 0.22 in 2004. Using standard decomposition techniques, this paper presents a preliminary investigation of the determinants of Brazil's distributional reversal over this period. The rise in inequality in the 1980s appears to have been driven by increases in the educational attainment of the population in a context of convex returns, and by high and accelerating inflation. While the secular decline in inequality, which began in 1993, is associated with declining inflation, it also appears to have been driven by four structural and policy changes which have so far not attracted sufficient attention in the literature, namely: sharp declines in the returns to education; pronounced rural-urban convergence; increases in social assistance transfers targeted to the poor; and a possible decline in racial inequality. Although poverty dynamics since the Real Plan of 1994 have been driven primarily by economic growth, the decline in inequality has also made a substantial contribution to poverty reduction.
\end{abstract}

\section{World Bank Policy Research Working Paper 3867, March 2006}

The Policy Research Working Paper Series disseminates the findings of work in progress to encourage the exchange of ideas about development issues. An objective of the series is to get the findings out quickly, even if the presentations are less than fully polished. The papers carry the names of the authors and should be cited accordingly. The findings, interpretations, and conclusions expressed in this paper are entirely those of the authors. They do not necessarily represent the view of the World Bank, its Executive Directors, or the countries they represent. Policy Research Working Papers are available online at http://econ.worldbank.org.

Acknowledgements: We would like to thank Rob Townsend for encouraging us to write this paper, and Martin Ravallion and one anonymous referee for very helpful comments. 


\section{1) Introduction.}

Measured by the Gini coefficient for the distribution of household income per capita, inequality in Brazil rose from 0.574 in 1981 to 0.625 in 1989. After that five-point (or 9\%) increase during the 1980s, Brazil's inequality was the second highest in the world, narrowly behind Sierra Leone's Gini of 0.629. From its peak of 0.625 in 1989, Brazil's Gini fell by six points, or roughly ten percent, to 0.564 in 2004. These are not insubstantial changes. According to World Bank (2005), the 2004 number would place Brazil as the tenth most unequal country in the world, behind Bolivia, Botswana, the Central African Republic, Guatemala, Haiti, Lesotho, Namibia, South Africa, and Zimbabwe. ${ }^{1}$

While Brazil's inequality level continues to be very high by international standards, its inequality has been less stable than is sometimes argued. ${ }^{2}$ Large changes had also occurred in earlier periods, with the Gini coefficient for the distribution of (adjusted) household per capita incomes as measured by the decennial Censuses, rising from around 0.500 in 1960 to 0.565 in 1970 (see Bonelli and Sedlacek, 1989). Inequality rose further between 1970 and 1976, reached a peak on that year, and then fell from 1977 to 1981. See Bonelli and Sedlacek (1989), Hoffman (1989) and Ramos (1993).

In this paper, we describe the evolution of inequality and poverty in Brazil from 1981 to 2004, drawing on one the longest time-series of broadly comparable annual household surveys available anywhere in the developing world. Using standard decomposition techniques, we also seek to identify candidate determinants for both the levels and the changes that we observe in inequality and, to a lesser extent, poverty. The paper is mostly descriptive, and the purpose of the decomposition analyses is simply to generate plausible hypotheses for the causal processes behind Brazil's distributional dynamics over the last two and a half decades. Sensible explanations must be

\footnotetext{
${ }^{1}$ While useful as motivation, international rankings of inequality are fraught with severe comparability problems. Some of the measures included refer to distributions of consumption expenditures, while others refer to income. Even across the same welfare concept, survey questionnaires and collection methods differ substantially across countries. Data for different years are included in the comparisons, and the coverage of countries has varied sharply over time. Data for Sierra Leone, for instance, is not included in the World Bank (2005) tables. A country's position in these rankings is therefore subject to considerable error and uncertainty, and should be taken as very roughly indicative only.

${ }^{2}$ See, for instance, Barros, Henriques and Mendonça (2000)'s well-known paper on “The Unacceptable Stability: Inequality and Poverty in Brazil" (our translation).
} 
consistent with the basic stylized facts that we discuss and, in that sense, this paper provides exploratory empirical analysis which might hopefully lay the foundation for future research. ${ }^{3}$

The evolution of inequality over this 23 -year period falls neatly into three main stages: a steady increase from 1981 to 1989; a highly volatile "peak period" between 1989 and 1993; and a steady decline from 1993 to 2004. Poverty was trendless but highly volatile during the 1980s, and declined steadily from 1993 onwards. The evidence suggests that the inequality increases of the 1980s were driven by high and accelerating inflation, and by a gradual expansion in the educational levels of the labor force which, in a context of increasing marginal returns to schooling, led to greater earnings inequality (see also Ferreira and Paes de Barros, 1999).

From 1993 onwards, four forces combined to reduce income inequality. First, income disparities across groups with different educational endowments have been falling, suggesting a secular decline in average returns to schooling. Second, there has been a remarkable convergence in household incomes between the country's rural and urban areas, which has replaced and added to the inter-state convergence that had been documented until the mid-1980s. Third, there has been a decline in absolute inter-racial inequality, which may or may not go beyond a reflection of the falling returns to schooling. Fourth, there is evidence of much more widespread receipts of cashbased social assistance transfers from the government, and some evidence that it is also better targeted. In addition to these four "structural" and policy processes, the macroeconomic stability ushered in by the Real Plan of 1994 has eliminated the contribution from hyper-inflation to inequality, which was present in the previous sub-period.

The paper is structured as follows. Section 2 contains a brief description of the data sets used in this analysis and of the main trends in poverty and inequality over the period. Section 3 reports on the static inequality decompositions carried out with three inequality measures, for the years 1981 , 1993 and 2004. ${ }^{4}$ These decompositions follow the method employed by Cowell and Jenkins (1995), and aim to separate total inequality levels into its components within and between groups, where

\footnotetext{
${ }^{3}$ This paper has originated from a request for an update of Ferreira and Litchfield (2001), which described distributional dynamics in Brazil from 1981 to 1995.

${ }^{4} 1981$ and 2004 are the initial and final years of the period we cover. 1993 emerges as a "watershed" year in Brazil's inequality and poverty dynamics. See Section 2.
} 
the groups are defined by specific household attributes, such as regional location, urban-rural status, or age, gender, race or education of the head.

However, the personal distribution of income does not only reflect differences in these household characteristics, but also differences in the extent to which households have access to formal employment, vis-à-vis a reliance on self-employment, and indeed variation in their access to capital or transfer incomes. Therefore, this section also examines the income sources of each household and their relationship with inequality in total household income per capita.

The next two sections turn to the dynamics of inequality and poverty. Section 4 discusses a dynamic decomposition methodology due to Mookherjee and Shorrocks (1982), which separates changes in inequality into components due to changes in the mean incomes of different groups, changes in the composition of these groups, and unexplained changes. It also presents the Datt and Ravallion (1992) decomposition of changes in poverty into a growth and a redistribution component. Section 5 briefly reports on the correlations between poverty, inequality and a couple of macroeconomic variables, focusing on the rate of inflation. Section 6 concludes and presents the candidate hypotheses that our analysis suggests might explain the recent changes in Brazil's income distribution. Some of the questions raised for future research are briefly discussed.

\section{2) The Data and What it Says.}

The data sets we use are the household-level micro-data from the Pesquisa Nacional por Amostra de Domicílios (PNAD) for 1981-2004, produced by the Instituto Brasileiro de Geografia e Estatística (IBGE) ${ }^{5}$. Data were collected each year from a representative national sample of households, with a sample size ranging from 291,000 to 525,000 individuals. ${ }^{6}$ The

\footnotetext{
${ }^{5}$ Three years are missing from the time series presented below: 1991 and 2000 were Census years, during which PNADs are not fielded. Income data from the Censuses are based on very different questionnaires, and are not comparable with PNAD data. The survey was not fielded in 1994 either, for cost-related reasons. 1982 is included but the reader is cautioned that income questions had a different reference period on that year. They were asked with respect to a quarter, rather than a month, giving rise to different recall periods. The answers are therefore not comparable with those from other surveys.

${ }^{6}$ Sample sizes rose gradually from 482,611 individuals in 1981 to 525,023 individuals in 1985 . The sample size was then scaled back to 290,518 in 1986, within the same sampling frame and with care to maintain representativeness. It then rose gradually to 389,073 in 2004. The PNAD survey is not carried out in the rural areas of the old North Region of Brazil, which roughly corresponds to the Amazon rainforest. The current North Region includes the state of Tocantins, which was previously part of Goiás state. The rural areas of this state are included in the PNAD throughout the time series.
} 
survey reports each year on a range of variables that form the basic data set. Questions are asked on subjects pertaining to the household and to individuals within the household. Information is recorded on the geographic location of the household; characteristics of the dwelling; household size; relationships between individuals in the household; activities of individuals; income from labor, transfers and other sources (such as land rents and capital); occupation and other labor characteristics; age; gender; education; ethnicity and literacy. The definition of income throughout the main analysis is gross monthly household income per capita and the population is all individuals in the population. ${ }^{7}$ Monetary amounts are all measured in 2004 Brazilian Reais, with a dollar exchange rate of $\mathrm{BR} \$ / \mathrm{US} \$=2.89 .{ }^{8}$ The Brazilian INPC official consumer price index, which is listed in Appendix 1, is used to convert current incomes into real incomes. For a more detailed description of the data set and methodology see Litchfield (2001).

This section presents summary statistics of the income distributions. Mean and median incomes are presented for each year in the series, along with four summary measures of inequality. These are the Gini coefficient ( Gini $=\frac{1}{2 n^{2} \bar{y}} \sum_{i=1}^{n} \sum_{j=1}^{n}\left|y_{i}-y_{j}\right|$ ) and three members of the Generalised Entropy (E) class of measures, $E(0)=\frac{1}{n} \sum_{i=1}^{n} \log \frac{\bar{y}}{y_{i}}$, also known as the mean log deviation or Theil - L; $\quad E(1)=\frac{1}{n} \sum_{i=1}^{n} \frac{y_{i}}{y} \log \frac{y_{i}}{y}$, also known as the Theil-T index; and $E(2)=\frac{1}{2 n \bar{y}^{2}} \sum_{i=1}^{n}\left(y_{i}-\bar{y}\right)^{2}$, which is half of the square of the Coefficient of Variation (CV). The Generalised Entropy class of measures is chosen because its members satisfy all of the desired axioms of inequality measures ${ }^{9}$. Whilst the Gini will only satisfy one of these principles under certain conditions, it is included in the analysis to allow some degree of comparability with other

\footnotetext{
${ }^{7}$ In this paper, we do not deflate the raw PNAD incomes by a regional price index, nor do we impute rents for owner-occupied housing, since the assumptions required about the stability of certain estimated relationships over 23 years were deemed too strong. The consumption surveys which could be used to generate nationwide regional price indices, for instance, are so far apart (1975 and 1996), as to make sensible comparisons of regionally deflated data over the period we are concerned with in this paper hazardous. See, however, Ferreira et. al. (2003) for results when these adjustments are carried out for a single point in time.

${ }^{8}$ This is the average nominal exchange rate for the survey reference month, September 2004.

9 These axioms are as follows: anonymity; the Pigou-Dalton transfer principle; scale invariance; population replication invariance; and decomposability (see Cowell, 1995).
} 
studies $^{10}$. The values for these indices for the period 1981-2004, along with the corresponding mean and median incomes, are presented in Table 1 below. ${ }^{11}$

Table 1: Brazil 1981-2004: Incomes and Summary Measures of Inequality

$\begin{array}{lcccccc}\text { Year } & \begin{array}{c}\text { Mean } \\ \text { income }\end{array} & \text { Median } & \text { Gini } & \mathbf{E ~ ( 0 )} & \mathbf{E}(\mathbf{1}) & \mathbf{E}(\mathbf{2}) \\ 1981 & 336.7 & 173.2 & 0.574 & 0.613 & 0.647 & 1.447 \\ 1982 & 348.5 & 178.9 & 0.581 & 0.629 & 0.669 & 1.552 \\ 1983 & 273.4 & 137.5 & 0.584 & 0.631 & 0.675 & 1.515 \\ 1984 & 273.2 & 136.3 & 0.583 & 0.626 & 0.679 & 1.464 \\ 1985 & 331.7 & 163.4 & 0.589 & 0.649 & 0.696 & 1.622 \\ 1986 & 483.6 & 249.4 & 0.578 & 0.620 & 0.673 & 1.637 \\ 1987 & 362.6 & 181.7 & 0.592 & 0.666 & 0.710 & 1.791 \\ 1988 & 338.9 & 161.1 & 0.609 & 0.714 & 0.750 & 1.742 \\ 1989 & 382.7 & 170.6 & 0.625 & 0.757 & 0.811 & 2.212 \\ 1990 & 347.3 & 167.5 & 0.604 & 0.700 & 0.735 & 1.767 \\ 1992 & 302.3 & 162.8 & 0.573 & 0.628 & 0.666 & 1.876 \\ 1993 & 320.7 & 157.2 & 0.595 & 0.678 & 0.743 & 2.308 \\ 1995 & 385.7 & 190.1 & 0.591 & 0.659 & 0.705 & 1.627 \\ 1996 & 393.9 & 194.1 & 0.591 & 0.664 & 0.700 & 1.609 \\ 1997 & 401.2 & 198.3 & 0.593 & 0.668 & 0.709 & 1.739 \\ 1998 & 404.0 & 203.7 & 0.591 & 0.658 & 0.707 & 1.672 \\ 1999 & 385.8 & 198.3 & 0.585 & 0.641 & 0.685 & 1.530 \\ 2001 & 393.4 & 199.2 & 0.586 & 0.646 & 0.697 & 1.661 \\ 2002 & 396.3 & 204.6 & 0.580 & 0.628 & 0.677 & 1.522 \\ 2003 & 381.2 & 201.7 & 0.575 & 0.619 & 0.663 & 1.474 \\ 2004 & 393.9 & 210.0 & 0.564 & 0.591 & 0.644 & 1.618\end{array}$

Note: Incomes are monthly household incomes per capita, measured in September 2004 Reais.

Source: Authors' calculations from the PNADs.

Two main features of the data jump out from Table 1. The first is the difference between mean and median income: the median-to-mean ratio ranges from 0.446 in 1989 to 0.539 in 1992. This

\footnotetext{
${ }^{10}$. The Gini coefficient is only perfectly decomposable when sub-groups of the population do not overlap in the space of incomes.

${ }^{11}$ While households with total incomes equal to zero are included in the distributions used to calculate mean and median incomes, as well as poverty measures, they are excluded from the calculations of inequality measures. Such households range from $0.5 \%$ to $2.0 \%$ of the sample. The Gini coefficient and E(2), which can also be computed including the zero values, are not much affected by this exclusion, as can be seen from the comparison in Appendix 3. Trends are entirely unaffected.
} 
indicates that the distribution was extremely skewed to the right, with $50 \%$ of the population receiving incomes less than approximately half of the arithmetic mean.

The second key feature of Table 1 is the inverted-U inequality dynamics, with the three subperiods previously mentioned: a steady increase from 1981 to 1989 (with the Gini rising from 0.574 to 0.625 ); a highly volatile "peak period" between 1989 and 1993; and a steady decline from 1993 to 2004 (with the Gini falling from 0.595 to 0.564). A very similar inverted-U pattern (with a volatile peak region) obtains for the other three inequality measures. ${ }^{12}$ Figure 1 plots the evolution of the Gini coefficient (on the left scale) and the two Theil indices (on the right scale) over the period.

Figure 1: Three Measures of Inequality in Brazil, 1981-2004

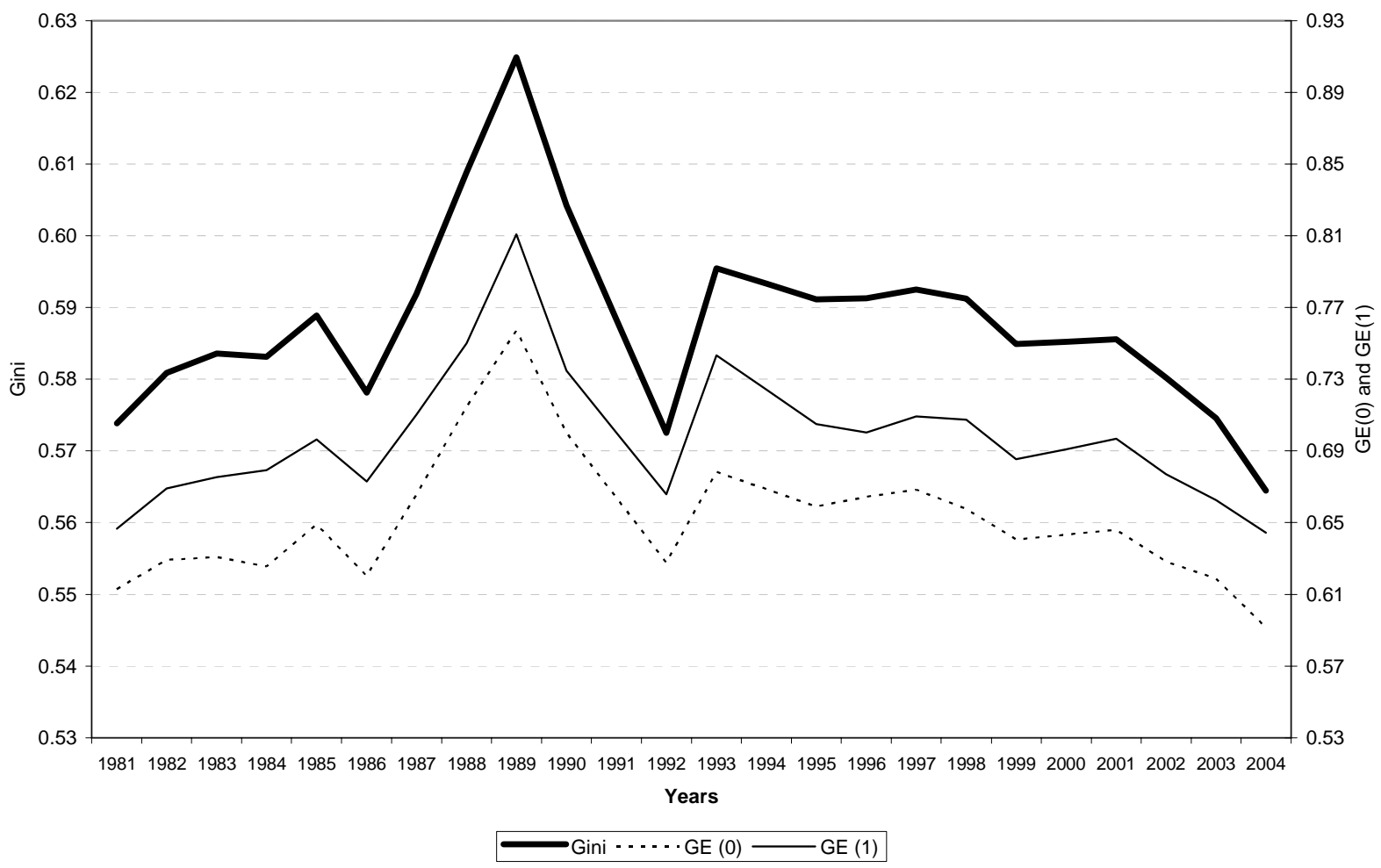

How about the dynamics of poverty over this period? Unlike many other countries, Brazil does not have an official poverty line. A set of regionally-specific poverty lines calculated by Rocha (1993) for use with PNAD 1990 data has historically been used by many researchers. Rocha

\footnotetext{
${ }^{12}$ The $\mathrm{E}(2)$ series is not shown on Figure 1, but it is similar and available from the authors upon request.
} 
begins by computing the minimum cost of food baskets required to attain the FAO-recommended caloric requirements. Because of substantial differences across the country's regions - and within these regions, from metropolitan to other urban areas and then to rural areas - in both consumption patterns and prices, a food basket was calculated for each area specifically. ${ }^{13}$ The food costs for each area therefore respect not only price differences, but also differences in tastes and local food availability. ${ }^{14}$ Rather than using the inverse of an Engel coefficient to obtain the poverty line, Rocha estimated non-food expenditure amongst the poor directly for each separate metropolitan area ${ }^{15}$. The sum of non-food expenditures amongst the poor and the cost of the food basket gives the set of regional poverty lines. The values of the region-specific poverty lines, in 2004 Reais, for the relevant PNAD regions are reported in Appendix 2, which is converted from table XIII in Rocha (1993).

Recently, however, an ad-hoc poverty line set at $\mathrm{R} \$ 100$ per capita per month (in 2004 values) has gained currency, largely because it corresponds to the means-test in Brazil's main new cash assistance program, Bolsa Família. Its increased usage in the press and in policy discussions is analogous to the use of "administrative" or "policy-based poverty lines", derived from benefit means-test income levels, in European countries. In what follows, we present the poverty series for both of these lines.

Table 2 reports the three standard FGT poverty measures: the headcount index; the normalized poverty deficit; and the FGT(2) measure. ${ }^{16}$ The corresponding time series are plotted in Figure 2. Over the period as a whole, all three poverty measures fell for both lines, although the declines were quantitatively modest for such a long period. The proportional decline in poverty incidence (according to the Administrative Poverty Line) from 0.296 to 0.222 is of exactly $25 \%$. This contrasts, for instance, with a poverty reduction of $62 \%$ (from 0.418 in 1975 to 0.157 in 1992) in

\footnotetext{
13 In fact, this was done for the nine metropolitan areas (Belém, Fortaleza, Recife, Salvador, Belo Horizonte, Rio de Janeiro, São Paulo, Curitiba and Porto Alegre), as well as Brasília and Goiânia, using the 1987 expenditure survey Pesquisa de Orçamentos Familiares (POF). For the other urban and rural areas, conversion factors were borrowed from an earlier work by Fava (1984), which was based on the most recent available data for these areas, namely the 1975 Estudo Nacional da Despesa Familiar (ENDEF). These were updated to 1990 prices using the INPC price index.

${ }^{14}$ For an alternative approach to dealing with regional differences in the cost of living, using a regional price index defined for a fixed basket, see Ferreira et. al. (2003).

15 'The poor' amongst whom she computes non-food expenditures are those who, according to information recorded in the POF, were unable to meet minimum caloric requirements as specified by FAO.
} 
Thailand, and a spectacular 82\% decline (from 0.643 in 1975 to 0.114 in 1995), in Indonesia, both achieved over shorter periods of time. ${ }^{17}$

Table 2. Brazil 1981-2004: Three Poverty Measures for two Poverty Lines

\begin{tabular}{lcccccc} 
Year & \multicolumn{3}{c}{ Regional Poverty Line $^{1}$} & \multicolumn{3}{c}{ Administrative Poverty Line $^{2}$} \\
& Headcount & Poverty Gap & FGT(2) & Headcount & Poverty Gap & FGT(2) \\
1981 & 0.399 & 0.163 & 0.090 & 0.296 & 0.124 & 0.070 \\
1982 & 0.392 & 0.160 & 0.088 & 0.293 & 0.123 & 0.070 \\
1983 & 0.512 & 0.229 & 0.133 & 0.383 & 0.170 & 0.099 \\
1984 & 0.503 & 0.222 & 0.127 & 0.379 & 0.163 & 0.093 \\
1985 & 0.435 & 0.183 & 0.102 & 0.317 & 0.133 & 0.075 \\
1986 & 0.266 & 0.096 & 0.049 & 0.185 & 0.069 & 0.036 \\
1987 & 0.405 & 0.171 & 0.097 & 0.297 & 0.127 & 0.073 \\
1988 & 0.455 & 0.202 & 0.119 & 0.338 & 0.152 & 0.091 \\
1989 & 0.437 & 0.194 & 0.114 & 0.315 & 0.142 & 0.084 \\
1990 & 0.445 & 0.196 & 0.115 & 0.328 & 0.147 & 0.088 \\
1992 & 0.456 & 0.209 & 0.128 & 0.325 & 0.150 & 0.093 \\
1993 & 0.466 & 0.215 & 0.130 & 0.326 & 0.151 & 0.093 \\
1995 & 0.380 & 0.164 & 0.095 & 0.277 & 0.117 & 0.070 \\
1996 & 0.378 & 0.167 & 0.101 & 0.273 & 0.122 & 0.075 \\
1997 & 0.370 & 0.162 & 0.096 & 0.273 & 0.116 & 0.071 \\
1998 & 0.363 & 0.156 & 0.091 & 0.251 & 0.110 & 0.066 \\
1999 & 0.375 & 0.161 & 0.094 & 0.256 & 0.112 & 0.067 \\
2001 & 0.375 & 0.166 & 0.100 & 0.258 & 0.113 & 0.069 \\
2002 & 0.365 & 0.156 & 0.090 & 0.245 & 0.102 & 0.060 \\
2003 & 0.373 & 0.163 & 0.097 & 0.249 & 0.106 & 0.064 \\
2004 & 0.345 & 0.145 & 0.083 & 0.222 & 0.093 & 0.054
\end{tabular}

Notes: 1 - Rocha (1993) regional poverty lines. See Appendix 2 for details. 2 - The "administrative poverty line" is set as $\mathrm{R} \$ 100$ per person per month, in September 2004 values.

Source: Authors' calculations from the PNADs.

Behind the overall decline, poverty dynamics in Brazil over the last two decades have been marked by considerable volatility, which largely reflected macroeconomic instability. Unsurprisingly, therefore, the volatility was more pronounced in the unstable decade of the 1980s, with a sharp increase during the 1981-83 recession, and a substantial decline during the recovery that took place between 1984 and 1986. All three measures are at their minimum in

\footnotetext{
${ }^{16}$ See Foster, Greer and Thorbecke (1984).

${ }^{17}$ The Thai (Indonesian) poverty incidence is calculated with respect to a poverty line of US\$2-a-day (US\$ 1-aday), both in 1985 prices and using PPP exchange rates. See Ahuja et. al. (1997, pp. 7 and 33).
} 
1986 and then rise again until 1988. Like the inequality measures, they fluctuate without a trend between 1989 and 1993, and then begin a sustained decline which lasts for the next eleven years.

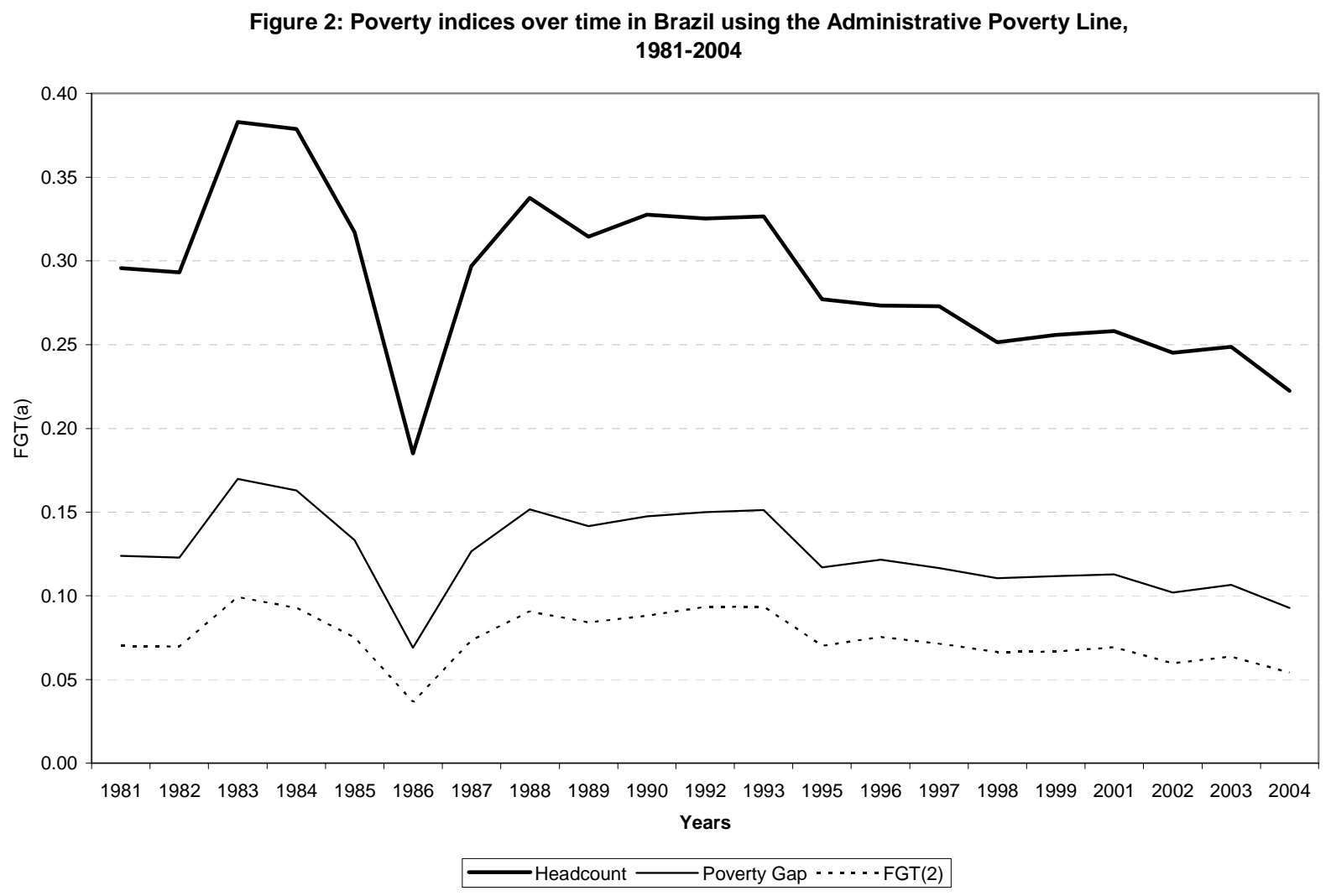

The poverty decline in 1986, which mirrors the enormous increase in mean and median incomes reported for that year in Table 1, deserves a word of explanation. These are the actual numbers from the PNAD survey, and they do not reflect any change in the questionnaire, reference period or survey design on that year. Despite considerable scrutiny from various authors, similar figures have been widely reported in the literature on Brazil, including Amadeo and Camargo (1997); Barros, Henriques and Mendonça (2000); and Ferreira and Litchfield (2000). The general view seems to be that this rise in mean incomes, and the corresponding decline in poverty, reflect the expansionary nature of the 1986 Cruzado stabilization plan. GDP grew by $7.5 \%$, and the FIESP industrial real wages by some $20 \%$ during that year, suggesting that part of the increase in the survey mean and the decline in poverty are likely to have been real.

Nevertheless, the increase in the PNAD survey mean between 1985 and 1986 is of $46 \%$, which is clearly inconsistent with the national accounts growth rate of $7.5 \%$. Clearly, the magnitudes of 
this single-year increase in 1986, and of the corresponding $40 \%$ proportional poverty decline reported in Table 2, are not credible. Since there were no methodological changes to the survey, the explanation for this discrepancy - which is unique in the Brazilian time series, as an inspection of Tables 1 and 2 will attest - is unlikely to be found in statistical problems like those which have recently featured in the literature on poverty in India. More likely, it reflects the disconnect between monetary incomes and welfare that resulted from the widespread rationing that became prevalent throughout the Brazilian economy in late 1986. Rationing arose in most consumer-goods sectors as continued monetary growth made the price freezes, on which the failed Cruzado stabilization plan hinged, unsustainable. Under widespread rationing, of course, real monetary incomes (calculated with respect to the prevailing frozen prices) are no longer a reliable guide to welfare, or to poverty, since goods are not necessarily available to meet demand.

As the price freeze became unsustainable, and black markets proliferated, the Cruzado Plan was abandoned, and an upsurge in inflation in 1987 restored equilibrium prices. The results can be seen in the "return to normalcy" of median, mean and poverty indicators for 1987, in Tables 1 and 2. Crucially, during September 1986 - the reference month for the PNAD survey - the price freeze (which was decreed on February $28^{\text {th }}, 1986$, and effectively abandoned with the "Cruzado II" announcement of November $21^{\text {st }}$ of the same year) was still firmly in place, but rationing and black markets were already commonplace. ${ }^{18}$ In sum, while we are confident that the time-series for poverty and inequality presented in Tables 1 and 2 are reasonably accurate for all other years, they clearly overstate mean incomes and understate poverty for 1986. Since there is no obvious reason why rationing should be distributionally neutral, the inequality numbers for 1986 must also be treated with circumspection.

Be that as it may, poverty was higher in 1993 than in 1981 for all six poverty series in Table 2 indicating that, at least in terms of income poverty reduction, the 1980 s really were a lost decade for Brazil. All of the overall reduction in poverty between 1981 and 2004 was therefore achieved between 1993 and 2004, a period marked by the restoration of macroeconomic stability, some modest resumption in growth, and sustained - if unspectacular - declines in inequality. While poverty reduction in this latter sub-period still falls short of the aforementioned Asian miracle

\footnotetext{
${ }^{18}$ See Lara Resende et. alli (1987).
} 
rates (or those of other fast-growing economies, from Chile to China), they are a little more respectable: incidence by the administrative poverty line fell by 10 percentage points (or 32\%) between 1993 and $2004 .^{19}$

\section{3) Static Decompositions of Brazilian Inequality.}

We now turn to an investigation of the structure of inequality in Brazil, both as relates to the nature of the households that receive income, and to the composition of the income flows they receive. Decompositions are carried out for three years: 1981, 1993 and 2004. In the first instance, we examine the role played by certain individual and family characteristics, through a set of static inequality decompositions by population subgroups. ${ }^{20}$ We concentrate on seven attributes of the household: its regional location; its urban/rural status; its demographic composition; as well as the age, gender, race and educational attainment of the household head. ${ }^{21}$ Choosing the partitions themselves, for example the break points between age groups, can be somewhat arbitrary. Our choices follow the partitions used in Ferreira and Litchfield (2001):

- Age of household head. Households are grouped into six categories by the age of the household head: i) under 25 , ii) 25-34, iii) 35-44, iv) 45-54, v) 55-64 and vi) 65+ years.

- Educational attainment of household head. This is measured as years of schooling, classified into five groups: (i) illiterates or those with less than one year of schooling; (ii) elementary school - 1-4 years; (iii) intermediate school - 5 to 8 years; (iv) high school - 9 to 11 years; and (v) college education, with 12 or more years of schooling.

- Gender of household head. Simply male or female.

- Race of household head. This is split into three categories: i) white, ii) Asian and iii) black and mixed race, including indigenous. Race in the PNAD is a self-reported variable, with no input from interviewer assessment. Unfortunately very little data is available for race

\footnotetext{
19 A more detailed description of poverty and inequality trends between 1981 and 1995, including a treatment of stochastic dominance and an assessment of sensitivity to equivalence scales, is provided in Ferreira and Litchfield (2000).

${ }^{20}$ These techniques were pioneered by Bourguignon (1979), Cowell (1980) and Shorrocks (1980, 1984).

21 PNAD interviewers were instructed to register as household head the person "responsible for the household or so perceived by the remaining members" (IBGE, 1993, p.16).
} 
during the 1980s. In 1981 the question did not appear in the core questionnaire and in 1985 less than $5 \%$ of the sample responded to the question. In the last two or three years of the 1980s the response rate to the race question grew, and it became almost universal following a successful information campaign implemented in the run-up to the 1991 Census $^{22}$. Hence race is only used here for the analysis of 1993 and 2004. Following the standard practice in studies of Brazil, mixed race heads of households are grouped together with black and indigenous heads.

- Household type. Five types of households are identified: (i) "single adult" households comprised of only one adult; (ii) "couple, no kids" households comprised of only adults, i.e. all aged over 14 or over; (iii) "couples with kids" households with more than 1 adult plus children; (iv) "single parent" households with a single adult plus children; and (v) elderly households whose head is aged 65 or over, with or without children. This is a simplification of the categories used by Tanner (1987) for Northeast Brazil.

- Region. There are five official, standard geographical regions in Brazil: North, Northeast, Southeast, South and Centre-West.

- Urban/Rural location of household. Urban and rural areas are those so defined by IBGE and used in the PNAD.

The point of the static decompositions is to separate total inequality in the distribution into a component of inequality between the above groups in each partition $\left(I_{B}\right)$ - the explained component - and the remaining within-group inequality $\left(I_{W}\right)$ - the unexplained component. Unfortunately, many widely used inequality measures are not decomposable, in the sense that overall inequality can not be related consistently to the constituent parts of the distribution. In particular, we are interested in measures where $I_{B}+I_{W}=I$. This is not generally true, for instance, of the Gini coefficient, but it is true of all members of the Generalised Entropy class of measures (see Cowell, 1995).

Let within-group inequality, $I_{W}$, be defined as follows: $I_{w}=\sum_{j=1}^{k} w_{j} E(\alpha)_{j}$, with $w_{j}=v_{j}^{\alpha} f_{j}^{1-\alpha}$, where $f_{j}$ is the population share and $v_{j}$ the income share of each subgroup $j, j=1,2, \ldots . k$. Between-

\footnotetext{
${ }^{22}$ This was the "Não Deixe a Sua Cor Passar em Branco" - or "Do not let your color go blank" - campaign. The Portuguese words for blank and white are the same.
} 
group inequality, $I_{B}$, is defined by assigning the mean income of group $j, \mu\left(y_{j}\right)$ to each member of the group and calculating:

$$
I_{B}=\frac{1}{\alpha^{2}-\alpha}\left[\sum_{j=1}^{k} f_{j}\left(\frac{\mu\left(y_{j}\right)}{\mu(y)}\right)^{\alpha}-1\right]
$$

Cowell and Jenkins (1995) then show that the within- and between-group components of inequality, defined as above, can be related to overall inequality in the simplest possible way: $\mathrm{I}_{\mathrm{B}}+$ $\mathrm{I}_{\mathrm{W}}=\mathrm{I}$. They then suggest an intuitive summary measure, $R_{B}$, of the amount of inequality explained by a particular characteristic or set of characteristics (i.e. by a partition $\Pi$ ): $R_{B}=\frac{I_{B}(\Pi)}{I}$.

The $R_{B}$ statistic, which can be interpreted as the share of total inequality which can be accounted for or 'explained' by the attributes defining partition $\Pi$, is presented in Table 3 for the two Theil indices described in Section 2, for partitions by each of the characteristics discussed earlier. ${ }^{23}$

Table 3. The Percentage of Total Income Inequality Accounted for by Between-Group Differences.

\begin{tabular}{lcccccc} 
& \multicolumn{2}{c}{1981} & \multicolumn{2}{c}{1993} & \multicolumn{2}{c}{2004} \\
& \multicolumn{2}{c}{$\mathrm{R}_{\mathrm{b}}$} & \multicolumn{2}{c}{$\mathrm{R}_{\mathrm{b}}$} & \multicolumn{2}{c}{$\mathrm{R}_{\mathrm{b}}$} \\
& $\mathrm{E}(0)$ & $\mathrm{E}(1)$ & $\mathrm{E}(0)$ & $\mathrm{E}(1)$ & $\mathrm{E}(0)$ & $\mathrm{E}(1)$ \\
Age & $1 \%$ & $1 \%$ & $1 \%$ & $1 \%$ & $3 \%$ & $2 \%$ \\
Education & $38 \%$ & $42 \%$ & $34 \%$ & $36 \%$ & $35 \%$ & $38 \%$ \\
Gender & $0 \%$ & $0 \%$ & $0 \%$ & $0 \%$ & $0 \%$ & $0 \%$ \\
Race & n.a. & n.a. & $13 \%$ & $11 \%$ & $12 \%$ & $11 \%$ \\
Family type & $6 \%$ & $7 \%$ & $6 \%$ & $7 \%$ & $10 \%$ & $11 \%$ \\
Region & $13 \%$ & $11 \%$ & $9 \%$ & $7 \%$ & $10 \%$ & $8 \%$ \\
Urban/rural & $17 \%$ & $13 \%$ & $9 \%$ & $6 \%$ & $7 \%$ & $5 \%$ \\
& & & & & & \\
Notes: Racial characteristics are not available for 1981. & & & & \\
Source: Authors' calculations from PNAD 1981, 1993 and 2004. & &
\end{tabular}

Taken together, the decomposition results are suggestive. Gender of the household head has no explanatory power at all. As we know that participation rates and wages differed significantly by gender in Brazil throughout this period, the nil share of gender in these decompositions must

23 The Theil-L index, or mean logarithmic deviation, is the $\mathrm{E}(0)$ measure; whereas the Theil-T index is the $\mathrm{E}(1)$ 
reflect the endogenous nature of the choices that determine headship status. ${ }^{24}$ It is plausible, for instance, that actual or potential labor earnings help determine selection into the population of women who head their own households. It is also possible that elderly women in receipt of a pension can afford to live by themselves, whereas poorer widows are forced to live with family. Be that as it may, the fact is that, statistically, no part of Brazil's inequality is accounted for by differences between households headed by males and those headed by females.

Age of the household head also has very low explanatory power, suggesting that lifecycle effects in the labor market are either weak, or average out within households. The rise in $R_{B}$ for age of the head in 2004 suggests that these lifecycle considerations may be gaining in importance.

The most important determinant of overall inequality is the educational attainment of the household head. Differences between group mean incomes account for between $34 \%$ and $42 \%$ of overall inequality, depending on the year and measure. This share is about three times as important as those of any other partition. Causality can not be inferred from a statistical decomposition, and it is possible that this reflects as much the effect of past family income and wealth on educational achievement, as of educational achievement on current incomes. Whatever the direction of causation, and the possible joint determination between income and education across generations, the data indicates that over a third of overall inequality in Brazil can be accounted for by differences across five groups of households, sorted by the education of the head. Interestingly, there is some evidence that this share, while still very significant, may have been falling over the last twenty-three years: the $R_{B}$ for both $E(0)$ and $E(1)$ is four-five percentage points lower in 1993 and 2004 than in 1981. We return to this trend in Section 4 below.

Family type, race, region and the urban or rural location of the household are also important determinants of overall inequality. Differences between households of different family type account for between $6 \%$ and 11\% of total inequality, with a considerable increase between 1993 and 2004. Racial differences explain between $11 \%$ and $13 \%$ of total inequality, and appear stable between 1993 and 2004. Regional differences account for between 7\% and 13\% of total

measure. Analogous decompositions for E(2) are less informative, but are available from the authors on request.

${ }^{24}$ In 1999, the gross ratio of female to male wages across all workers in Brazil was 0.65. A gap remained even after controlling for various observed worker characteristics (De Ferranti et. al., 2004, Ch. 3.). See also Leme and Wajnman (2001). 
inequality and differences between urban and rural areas explain between $5 \%$ and $17 \%$ of total inequality.

Perhaps the most remarkable changes across the years in Table 3 pertain to the two spatial partitions. The importance of inter-regional inequality declines by three percentage points, or roughly a quarter, over the period. The rural/urban decomposition suffers an even more pronounced loss in importance - of roughly $60 \%$ - suggesting a process of income convergence between the rural and urban areas of the country. The decline in regional inequality is consistent with the evidence on convergence across states and regions in Brazil, and suggests that $\beta$ convergence has indeed been translating into $\sigma$-convergence although, as suggested by Afonso Ferreira (2000), the latter rate may have slowed in the $1990 \mathrm{~s}^{25}$ The rural-urban convergence, which is even more pronounced, but has been less studied, is consistent with the sectoral evidence on agricultural and agriculture-related business growth in Brazil since the trade liberalization of the early 1990s, and suggests future research questions as to whether the impact of regime change between import-substitution and a more outward-oriented development strategy might have contributed to the observed decline in inequality, at least in part through rural-urban convergence.

An alternative way to investigate the statistical structure of income inequality at any point in time is to ask how different income sources contribute to overall dispersion. This section concludes with a brief examination of that question, following a methodology of inequality decomposition by factor components developed by Shorrocks (1982). Table 4 presents the results of this decomposition for five income sources: earnings from employment (formal and informal); selfemployment incomes; labor incomes of employers; social insurance transfers; and a residual category that consists largely of capital incomes and social assistance transfers. For each income source $f$, Table 4 shows (absolute and relative) mean incomes; the inequality measure $\mathrm{E}(2)$; and the correlation of that income source with total household income. These are the three factors that determine the contribution of a particular source of income to total inequality. $S f$ ( $s f$ ) then denotes the absolute (proportional) share of a particular income source $f$ in total inequality. A large value indicates a large contribution to overall inequality.

25 A. Ferreira suggests that $\sigma$-convergence slows from 1986 onwards. See also Azzoni (1994) and Ellery Jr. and P. 
Table 4: The Contribution of Income Sources to Total Household Income Inequality in 1981, 1993 and 2004.

\begin{tabular}{|c|c|c|c|c|c|c|}
\hline & $\begin{array}{c}\text { Total } \\
\text { Household } \\
\text { Income per } \\
\text { Capita } \\
\end{array}$ & $\begin{array}{l}\text { Total Earnings } \\
\text { from } \\
\text { Employment* }\end{array}$ & $\begin{array}{c}\text { Total Income } \\
\text { from Self- } \\
\text { Employment } * *\end{array}$ & $\begin{array}{c}\text { Total Employer } \\
\text { Income*** }\end{array}$ & $\begin{array}{c}\text { Total Social } \\
\text { Insurance } \\
\text { Transfers \# }\end{array}$ & $\begin{array}{l}\text { All Other } \\
\text { Incomes \#\# }\end{array}$ \\
\hline \multicolumn{7}{|c|}{1981} \\
\hline Mean & 336.71 & 196.33 & 58.04 & 32.92 & 32.02 & 17.41 \\
\hline $\mathrm{E}(2)$ & 1.447 & 2.097 & 5.147 & 31.000 & 11.502 & 33.106 \\
\hline $\begin{array}{l}\text { Correlation with household } \\
\text { income }\left(\rho_{\mathrm{f}}\right)\end{array}$ & 1 & 0.709 & 0.268 & 0.472 & 0.356 & 0.429 \\
\hline Relative mean $\left(\chi_{\mathrm{f}}\right)$ & 1 & 0.583 & 0.172 & 0.098 & 0.095 & 0.052 \\
\hline $\begin{array}{l}\text { Absolute factor contribution } \\
\left(S_{\mathrm{f}}\right)\end{array}$ & 1.447 & 0.720 & 0.126 & 0.309 & 0.138 & 0.153 \\
\hline $\begin{array}{l}\text { Proportionate factor } \\
\text { contribution }\left(s_{\mathbf{f}}\right)\end{array}$ & 1 & 0.498 & 0.087 & 0.214 & 0.095 & 0.106 \\
\hline $\mathrm{E}(2), \mathrm{y}_{\mathrm{f}}>0$ & 1.447 & 1.352 & 1.658 & 1.193 & 2.325 & 4.413 \\
\hline Pop share with $y_{f}>0$ & 1 & 0.713 & 0.382 & 0.054 & 0.235 & 0.146 \\
\hline \multicolumn{7}{|c|}{1993} \\
\hline Mean & 320.73 & 166.15 & 57.80 & 37.55 & 45.27 & 13.95 \\
\hline $\mathrm{E}(2)$ & 2.308 & 3.115 & 7.626 & 51.177 & 9.386 & 49.332 \\
\hline $\begin{array}{l}\text { Correlation with household } \\
\text { income }\left(\rho_{\mathrm{f}}\right)\end{array}$ & 1 & 0.615 & 0.319 & 0.584 & 0.345 & 0.400 \\
\hline Relative mean $\left(\chi_{\mathrm{f}}\right)$ & 1 & 0.518 & 0.180 & 0.117 & 0.141 & 0.044 \\
\hline $\begin{array}{l}\text { Absolute factor contribution } \\
\left(S_{\mathrm{f}}\right)\end{array}$ & 2.308 & 0.854 & 0.241 & 0.743 & 0.227 & 0.243 \\
\hline $\begin{array}{l}\text { Proportionate factor } \\
\text { contribution }\left(\mathrm{s}_{\mathrm{f}}\right)\end{array}$ & 1 & 0.370 & 0.104 & 0.322 & 0.098 & 0.105 \\
\hline $\mathrm{E}(2), \mathrm{y}_{\mathrm{f}}>0$ & 2.308 & 2.106 & 2.467 & 2.510 & 2.288 & 7.433 \\
\hline Pop share with $\mathrm{y}_{\mathrm{f}}>0$ & 1 & 0.721 & 0.365 & 0.058 & 0.282 & 0.159 \\
\hline \multicolumn{7}{|c|}{2004} \\
\hline Mean & 393.88 & 196.06 & 60.76 & 44.12 & 76.82 & 16.11 \\
\hline $\mathrm{E}(2)$ & 1.618 & 2.101 & 6.801 & 43.301 & 6.925 & 23.090 \\
\hline $\begin{array}{l}\text { Correlation with household } \\
\text { income }\left(\rho_{\mathrm{f}}\right)\end{array}$ & 1 & 0.569 & 0.310 & 0.598 & 0.443 & 0.299 \\
\hline Relative mean $\left(\chi_{\mathrm{f}}\right)$ & 1 & 0.498 & 0.154 & 0.112 & 0.195 & 0.041 \\
\hline $\begin{array}{l}\text { Absolute factor contribution } \\
\left(S_{\mathrm{f}}\right)\end{array}$ & 1.618 & 0.522 & 0.158 & 0.561 & 0.289 & 0.088 \\
\hline $\begin{array}{l}\text { Proportionate factor } \\
\text { contribution }\left(\mathrm{s}_{\mathrm{f}}\right)\end{array}$ & 1 & 0.323 & 0.098 & 0.347 & 0.179 & 0.054 \\
\hline $\mathrm{E}(2), \mathrm{y}_{\mathrm{f}}>0$ & 1.618 & 1.365 & 1.991 & 2.115 & 1.923 & 6.567 \\
\hline Pop share with $\mathrm{y}_{\mathrm{f}}>0$ & 1 & 0.717 & 0.341 & 0.060 & 0.326 & 0.300 \\
\hline $\begin{array}{l}\text { * Includes all earnings from } \\
\text { ** Includes all income from } \\
\text { *** Includes all incomes des } \\
\text { \# Includes all occupational p } \\
\text { \#\# Includes all social assistan } \\
\text { Notes: all incomes are in per } \\
\text { Source: Author's calculation }\end{array}$ & $\begin{array}{l}\text { formal (com ca } \\
\text { account (conta- } \\
\text { d as labor rem } \\
\text { ns, retirement } \\
\text { ansfers, capital } \\
\text { ta terms, and ar } \\
\text { n PNAD 1981, }\end{array}$ & $\begin{array}{l}\text { eira) and informal } \\
\text { rópria) activities. } \\
\text { eration to employe } \\
\text { comes and other s } \\
\text { ncomes, and incon } \\
\text { measured in Septe } \\
993 \text { and } 2004 \text {. }\end{array}$ & $\begin{array}{l}\text { sem carteira) emp } \\
\text { s. } \\
\text { cial security incon } \\
\text { es from rents. } \\
\text { nber } 2004 \text { Reais. }\end{array}$ & $\begin{array}{l}\text { loyment. } \\
\text { nes, but NOT socia }\end{array}$ & ssistance trans & \\
\hline
\end{tabular}

\footnotetext{
C. Ferreira (1994).
} 
The value of $\mathrm{E}(2)$ is always higher for individual income sources than for total income. It also varies a lot across income sources, from "lows" of 2.1 to 3.1 for earnings from employment, to highs of around 50.0 for employer's incomes and for capital and transfer incomes in 1993! These extremely high values arise mainly from the fact that most households receive zero incomes from the relevant income sources. The E(2) entries in the second row of each panel in Table 4 measure the level of inequality across all households, regardless of whether they actually receive any income from a particular source. But while earnings from employment accrue to $71 \%-72 \%$ of all households in all three years, only 5\%-6\% of households receive any income as employers. The last two rows of Table 4 present the population share of households receiving positive amounts from each income source, and $E(2)$ for positive incomes only. In this row, the value of $E(2)$ drops precipitously for all income sources - and most pronouncedly for those which accrue only to a minority of households. Even among recipients, however, inequality still remains very high for the "all other incomes" category. ${ }^{26}$ For the purpose of the decomposition of total household income inequality by source, all households must be considered in each calculation.

As in most countries, earnings from employment account for the largest share of total household per capita incomes in Brazil - declining from almost $60 \%$ to $50 \%$ over the period. The share of income from self-employment rises in 1993 and then falls to $15 \%$ by 2004 . The declining shares of income from employment and self-employment are compensated by rising shares for the labor income of employers and, most importantly, for social security incomes. The relative mean for social security transfers doubles from $10 \%$ in 1981 to $20 \%$ in 2004, reflecting both the ageing of the population and the expansion and growing generosity of Brazil's social security system (which is therefore likely to be unsustainable). Unfortunately, this expansion has taken place in a regressive manner, with the correlation between social security incomes and total household incomes rising from 0.36 in 1981 to 0.44 in 2004.

Social assistance transfers - including programs such as the old Bolsa Escola and the new Bolsa Família - are not included with social security incomes. Instead, they are lumped together with

\footnotetext{
26 This is as one might expect from the heterogeneous composition of this residual income category, which includes potentially large rental and capital incomes accruing to rich respondents, as well as small cash transfers to very poor households. With recent improvements in the disaggregation of the PNAD questionnaire, it would already have been possible - albeit still with some assumptions - to separate these disparate income sources for 2004. But this is not possible for earlier years.
} 
"other incomes", including any capital and rental incomes that are reported in the survey. This unsatisfactory state of affairs is in the process of being remedied, and the 2004 PNAD questionnaire already contains more detailed questions on transfer incomes than in the past, although not yet on specific amounts. In any case, for comparability with previous years, social assistance transfers must still be grouped within this residual category.

While this conflation prevents a confident assessment, there is some tentative evidence in Table 4 that recent increases in volume and better targeting of social assistance transfers are beginning to have some impact. From 1993 to 2004, mean "other" incomes have risen, and their inequality level has fallen dramatically from 49 to 23 . The population share receiving incomes from this source has almost doubled, from $16 \%$ to $30 \%$. Inequality amongst recipients has also fallen, from 7.4 to 6.6. Perhaps most tellingly, the correlation between this income source and total income has fallen from $40 \%$ to $30 \%$. While it is possible that these changes reflect changes in the distribution (or the reporting) of capital or rental incomes, it is more likely that they reflect, at least in part, the substantial expansion of Brazil's cash-based social assistance system, beginning with the Projeto Alvorada in 1994-95, the launch of the National Bolsa Escola and Bolsa Alimentação programs in 2000, and their integration into the Bolsa Família in 2003. A more disaggregated analysis of the incidence of these transfers over the last ten or fifteen years is needed in order to form an assessment of their role in the decline in overall inequality observed in Brazil over the period.

\section{4) The Dynamic Decomposition of Brazilian Inequality.}

Comparing static decompositions of inequality, whether by population subgroup or by income source, at different points in time may be informative about the changing structure of the income distribution. But dynamic decompositions of both inequality and poverty are a more direct approach to gaining insight into the factors associated with changes in those variables. In this section, we report on a dynamic decomposition of inequality (measured by $\mathrm{E}(0)$ ) proposed by Mookherjee and Shorrocks (1982), and then on a decomposition of poverty changes into a growth and a redistribution component, due to Datt and Ravallion (1992).

Accounting for changes in an overall measure of inequality - such as $\mathrm{E}(0)$ - by means of a partition of the distribution into population subgroups must entail at least two components to the change: one 
caused by a change in inequality between the groups, and another by a change in inequality within the groups. The first one is naturally the part of the total change 'explained' by the partition, whereas the second is a "pure inequality" or unexplained effect. But the explained component can be further disaggregated into an effect due to changes in relative mean incomes between the subgroups - an "income effect" - and another due to changes in the size or membership of the subgroups - an "allocation effect". The Mookherjee and Shorrocks (1982) procedure captures these three effects in an intuitive way. It allows the change in overall inequality to be decomposed into four terms as follows ${ }^{27}$ :

$$
\Delta E(0) \cong\left[\begin{array}{l}
\sum_{j=1}^{k} \overline{f_{j}} \Delta E(0)_{j} \\
+\sum_{j=1}^{k} \overline{E(0)_{j}} \Delta f_{j}+\sum_{j=1}^{k}\left[\overline{\lambda_{j}}-\overline{\log \left(\lambda_{j}\right)}\right] \Delta f_{j} \\
+\sum_{j=1}^{k}\left(\overline{v_{j}}-\overline{f_{j}}\right) \Delta \log \left(\mu\left(y_{j}\right)\right)
\end{array}\right]
$$

where $\Delta$ is the difference operator, $f_{j}$ is the population share of group $j, \lambda_{j}$ is the mean income of group $j$ relative to the overall mean, i.e. $\mu\left(\boldsymbol{y}_{j}\right) / \mu(\boldsymbol{y})$, and the overbar indicates an average value for the variable between the initial and final periods. The first term $(a)$ in the equation above captures the unexplained, or pure inequality effect. The second and third terms ( $b$ and $c$ ) capture the allocation effect, holding within-group inequality and relative mean incomes constant in turns. The final term (d) corresponds to the income effect.

By dividing both sides through by $\mathrm{E}(0)_{\mathrm{t}}$, proportional changes in overall inequality can be compared to proportional changes in the individual effects (Jenkins, 1995). It is then straightforward to draw conclusions about the importance of each effect in accounting for changes in the total. Changes in terms $b, c$ or $d$ indicate the extent to which changes in mean incomes for the different groups, or in their composition, explain the observed changes in total $\mathrm{E}(0)$. Changes in the first component - the pure inequality effect - are the unexplained changes, due to greater or lesser inequality within the groups. Table 5 shows the dynamic decomposition results for three time periods, the "rising

\footnotetext{
27 This is actually an approximation to the true decomposition, but both Mookherjee and Shorrocks (1982) and, later, Jenkins (1995) argue that for computational purposes this approximation is sufficient.
} 
inequality" years of 1981 to 1993; the "falling inequality" years of 1993 to 2004; and the entire period: 1981 to 2004 , over which there is a very small decline in $\mathrm{E}(0)$.

Table 5. A Decomposition of Changes in Inequality by Population Subgroups.

\begin{tabular}{|c|c|c|c|c|c|c|c|c|c|c|c|c|}
\hline \multirow{4}{*}{$\begin{array}{l}\text { Observed } \\
\text { Proportional } \\
\text { change in } \mathrm{E}(0)\end{array}$} & \multicolumn{4}{|c|}{ 1981-1993 } & \multicolumn{4}{|c|}{ 1993-2004 } & \multicolumn{4}{|c|}{ 1981-2004 } \\
\hline & \multirow{2}{*}{\multicolumn{4}{|c|}{0.107}} & \multirow{2}{*}{\multicolumn{4}{|c|}{-0.128}} & \multirow{2}{*}{\multicolumn{4}{|c|}{-0.035}} \\
\hline & & & & & & & & & & & & \\
\hline & a & $\mathrm{b}$ & $\mathrm{c}$ & d & a & $\mathrm{b}$ & $\mathrm{c}$ & $\mathrm{d}$ & a & $\mathrm{b}$ & $\mathrm{c}$ & d \\
\hline Age & 0.112 & -0.003 & 0.000 & 0.002 & -0.139 & -0.002 & 0.000 & 0.017 & -0.044 & -0.003 & 0.000 & 0.019 \\
\hline Education & 0.110 & 0.000 & 0.043 & -0.035 & -0.089 & 0.001 & 0.019 & -0.053 & 0.011 & 0.001 & 0.088 & -0.136 \\
\hline Family Type & 0.120 & -0.005 & 0.015 & -0.004 & -0.138 & -0.005 & 0.022 & 0.005 & -0.039 & -0.004 & 0.040 & -0.032 \\
\hline Gender & 0.116 & -0.005 & 0.000 & 0.000 & -0.120 & -0.004 & 0.000 & 0.000 & -0.018 & -0.009 & 0.000 & -0.001 \\
\hline Race & n.a. & n.a. & n.a. & n.a. & -0.101 & -0.003 & 0.001 & -0.021 & n.a. & n.a. & n.a. & n.a. \\
\hline Region & 0.141 & -0.003 & -0.003 & -0.024 & -0.118 & -0.001 & -0.001 & -0.005 & 0.012 & -0.005 & -0.004 & -0.028 \\
\hline Urban/rural & 0.178 & 0.005 & -0.032 & -0.040 & -0.104 & 0.002 & -0.014 & -0.009 & 0.054 & 0.017 & -0.048 & -0.049 \\
\hline
\end{tabular}

The first noteworthy feature of Table 5 is the asymmetry in the "explanatory power" of the partitions in the two sub-periods. Between 1981 and 1993, the pure inequality effect (the unexplained term $a$ ) is greater than the observed change (of 0.107 ) in $\mathrm{E}(0)$ for all partitions. This implies that changes in relative means or group compositions across the various population subgroups in all of these partitions can not account for the substantial increase in inequality over this period. Regional convergence, and convergence between urban and rural areas did take place, with substantial negative income effects for both of those partitions. There is also a negative allocation effect in the urban-rural partition, suggesting that the pattern of rural-urban migration in this period was inequality-reducing. But all of these effects go in the opposite direction to the overall increase, so the within-group increase in inequality compensates for those declines.

There were also changes in the educational partition, but they offset each other. Term $c$ indicates a measurable increase in inequality arising from changes in the composition of the education subgroups. We know from Ferreira and Litchfield (2001) that this reflects an expansion in the education of the labor force, with declines in the illiterate and primary population shares, and corresponding increases in the intermediate and high-school groups. We also know from Ferreira 
and Paes de Barros (1999) that the impact of this educational expansion - which might be inequality-reducing in a different context - contributed to an increase in inequality in Brazil because of the convexity of returns to schooling. It was largely offset, however, by a decline in the average returns to education which already appeared to be occurring during 1981-1993, and which presumably represented a price response to the increased supply of skills. This decline of $3.5 \%$ in the Theil-L can be seen in term $d$ in the education partition. The upshot is that this decomposition exercise can not shed much light on what was driving the increase in inequality over this period. We return to this question in the next section.

From 1993 to 2004, however, the decomposition gives us more clues to account for the observed $13 \%$ decline in inequality. 5.3 percentage points alone are accounted for by the reduction in inequality among means of the different educational sub-groups, which we interpret as evidence of a continued decline in the returns to formal schooling. Unlike in the previous sub-period, the allocation effects which reflect the continued increases in schooling in the labor force were now insufficient to offset the bulk of this effect, implying that the reductions in inequality among educational groupings did contribute with some $30 \%$ of the overall decline.

Additional declines of almost 3 percentage points (or around 20\% of the observed decline) are associated with reductions in inequality among racial groups, and between urban and rural areas. The partitions by family type; age and gender of the household head have no explanatory power. The proportional declines which can be accounted for by the educational, racial and urban-rural partitions are, of course, not additive. Each decomposition is independent of the others, and does not control for any other attribute. It is possible, therefore, that some (or all) of the negative income effect between racial groups in fact reflects the decline in educational inequalities. A similar, if less plausible, caveat could be made about the urban-rural differences.

The absence of controls is one reason why scalar inequality decompositions such as these are at best merely suggestive of the causal factors underlying distributional dynamics. Greater insight can be gained from counterfactual micro-simulation analysis, where the various candidate explanations can be combined and their partial contributions better assessed. Microsimulations also allow for a more disaggregated investigation of the entire distribution, rather than restricting 
the analysis to a single measure of dispersion. ${ }^{28}$ While microsimulation-based disaggregated decompositions have been conducted for Brazil in other periods ${ }^{29}$, a more detailed analysis of the 1993-2004 inequality decline must be left for future research. In that context, the contribution of the present paper is to describe the poverty and inequality dynamics and - on the basis of this exploratory decomposition analysis - to identify the main candidate explanations. Table 5 suggests that these explanations include: (i) a continuing decline in inequality across educational sub-groups, presumably driven by falling average returns to schooling; (ii) continuing convergence in incomes between the country's urban and rural areas; and (iii) a potential decline in racial inequalities. When one looks at the entire 1981-2004 period, one must add (iv) regional convergence, to the list.

What can be said about the temporal evolution of poverty, which was described in Table 2 and Figure 2, over the same period? Table 6 below reports on a now standard decomposition of poverty changes, into its growth and redistribution components. Originally suggested by Datt and Ravallion (1992), the decomposition is given by:

$$
\Delta P=P_{t+n}-P_{t}=\left[P\left(\frac{z}{\mu_{t+n}}, L_{t}\right)-P\left(\frac{z}{\mu_{t}}, L_{t}\right)\right]+\left[P\left(\frac{z}{\mu_{t}}, L_{t+n}\right)-P\left(\frac{z}{\mu_{t}}, L_{t}\right)\right]+R_{t}
$$

Where $z$ denotes a poverty line that is constant in real terms, $L_{t}$ denotes the Lorenz curve at time $\mathrm{t}$, and $\mu_{t}$ denotes the distribution's mean at time t. The first term (in squared brackets) on the righthand side is therefore the growth component, which is calculated by holding the Lorenz curve constant. The second term (in squared brackets) is the redistribution component, which holds the mean constant and allows for the Lorenz curve to change. ${ }^{30}$ The decomposition is path-dependent, and the terms would be somewhat different if the reference year was $t+n$, rather than $t$. Because of this path-dependence, there is a residual term when the decomposition is calculated for a single reference year $\mathrm{t}$, denoted $R_{t}{ }^{31}$

\footnotetext{
${ }^{28}$ Bourguignon, Ferreira and Lustig (2005) discuss the advantages of a disaggregated counterfactual analysis of distributional dynamics, and propose a general methodological framework.

${ }^{29}$ See Ferreira and Paes de Barros (1999).

${ }^{30}$ Datt and Ravallion (1992) rely on grouped data, and must therefore use parameterized estimates of the Lorenz curve in order to simulate the counterfactual distributions. Because we use household level data, we compute the counterfactual poverty terms $\mathrm{P}\left(\mathrm{z} / \mu_{\mathrm{x}}, \mathrm{L}_{\mathrm{y}}\right), \mathrm{x} \neq \mathrm{y}$, by rescaling the distribution in year $\mathrm{y}$ with the ratio $\mu_{\mathrm{x}} / \mu_{\mathrm{y}}$.

${ }^{31}$ As Datt and Ravallion suggest, this residual term can be interpreted as capturing the interaction between growth
} 
Table 6 lists the growth, redistribution and residual components of poverty changes for the subperiods 1981-1993 and 1993-2004, as well as for the whole period 1981-2004. This is done both for Rocha (1993)'s region-specific poverty lines, and for the “administrative poverty line” of R $\$ 100$ per capita per month. In the discussion, we refer predominantly to the administrative poverty line numbers.

Table 6: Brazil 1981-2004: Decomposition of Changes in Poverty into Growth and Redistribution Components

\begin{tabular}{lcccccc}
\hline & \multicolumn{3}{c}{ Regional Poverty Line $^{\mathbf{1}}$} & \multicolumn{3}{c}{ Administrative Poverty Line $^{2}$} \\
& Headcount & Poverty Gap & FGT(2) & Headcount & Poverty Gap & FGT(2) \\
$\mathbf{1 9 8 1}$ & 0.399 & 0.163 & 0.090 & 0.296 & 0.124 & 0.070 \\
$\mathbf{1 9 9 3}$ & 0.466 & 0.215 & 0.130 & 0.326 & 0.151 & 0.093 \\
Observed Change & $\mathbf{0 . 0 6 7}$ & $\mathbf{0 . 0 5 2}$ & $\mathbf{0 . 0 4 0}$ & $\mathbf{0 . 0 3 1}$ & $\mathbf{0 . 0 2 7}$ & $\mathbf{0 . 0 2 3}$ \\
Growth & 0.023 & 0.012 & 0.007 & 0.017 & 0.009 & 0.006 \\
Redistribution & 0.048 & 0.039 & 0.032 & 0.018 & 0.019 & 0.018 \\
Residual & -0.003 & 0.000 & 0.001 & -0.004 & 0.000 & 0.000 \\
& & & & & & \\
$\mathbf{1 9 9 3}$ & 0.466 & 0.215 & 0.130 & 0.326 & 0.151 & 0.093 \\
$\mathbf{2 0 0 4}$ & 0.345 & 0.145 & 0.083 & 0.222 & 0.093 & 0.054 \\
Observed Change & $\mathbf{- 0 . 1 2 1}$ & $\mathbf{- 0 . 0 7 0}$ & $\mathbf{- 0 . 0 4 7}$ & $\mathbf{- 0 . 1 0 4}$ & $\mathbf{- 0 . 0 5 9}$ & $\mathbf{- 0 . 0 3 9}$ \\
Growth & -0.089 & -0.049 & -0.032 & -0.062 & -0.034 & -0.022 \\
Redistribution & -0.035 & -0.023 & -0.018 & -0.035 & -0.027 & -0.020 \\
Residual & 0.003 & 0.002 & 0.002 & -0.007 & 0.002 & 0.003 \\
& & & & & & \\
1981 & 0.399 & 0.163 & 0.090 & 0.296 & 0.124 & 0.070 \\
2004 & 0.345 & 0.145 & 0.083 & 0.222 & 0.093 & 0.054 \\
Observed Change & $\mathbf{- . 0 5 4}$ & $\mathbf{- 0 . 0 1 8}$ & $\mathbf{- 0 . 0 0 7}$ & $\mathbf{- 0 . 0 7 3}$ & $\mathbf{- 0 . 0 3 1}$ & $\mathbf{- 0 . 0 1 6}$ \\
Growth & -0.070 & -0.035 & -0.021 & -0.052 & -0.026 & -0.016 \\
Redistribution & 0.013 & 0.017 & 0.015 & -0.019 & -0.007 & -0.002 \\
Residual & 0.004 & 0.000 & -0.001 & -0.002 & 0.002 & 0.002
\end{tabular}

Source: Author's calculations from PNAD's.

Note: 1 - From Rocha (1993). See disaggregated line values in Appendix 2

2 - Poverty line set as R\$100 in September 2004 values.

By all three FGT measures, and for both lines, poverty rose during 1981-1993 and then fell during 1993-2004. The decline in the second sub-period was sufficient to imply a decline over the entire period. In terms of poverty incidence, the rise in 1981-1993 was of 3 percentage points, followed by a decline of ten percentage points (or almost a third) to 0.22 in 2004. During both sub-periods, the growth and inequality components moved together. Rising poverty during the 1980s was driven 
both by economic contraction (mean income in the PNAD sample fell from $\mathrm{R} \$ 332$ in 1981 to $\mathrm{R} \$ 316$ in 1993) and by rising inequality, but rising inequality was the dominant force. The redistribution component was the larger force behind increasing poverty between 1981 and 1993, across all poverty lines and measures, and its power was greatest for the most bottom-sensitive poverty measures, the poverty gap and FGT(2).

With the advent of economic stability, both components changed sign. From 1993 to 2004, both growth and falling inequality contributed to declining poverty although, this time, the growth component dominated. Of the ten-point decline in poverty incidence, over six points are accounted for by growth, with redistribution responding for 3.5 points. The redistribution share does improve for FGT (1) and (2). Looking at the whole 1981-2004 period, there was a net decline of some seven percentage points in poverty incidence, five of which are attributable to growth, and two to redistribution. $^{32}$

\section{5) The Impact of Macroeconomic Performance.}

The dynamic decompositions in the previous section shed some light on the changes in Brazilian inequality and poverty over the last two and a half decades. In particular, a convergence in mean incomes between urban and rural areas; a reduction in average returns to education; and possibly a decline in inter-racial disparities seem to account for at least part of the decline in inequality during 1993-2004. As we learned from the decomposition by income sources in Section 3, larger volumes of better-targeted social assistance transfers may also have contributed.

But the picture was less clear for the increase in inequality during 1981-1993, when changes in the distribution of education appear to account for only a small part of the substantial overall increase in inequality, and the other decompositions fail to explain much. ${ }^{33}$ Bearing in mind that the outstanding economic fact of the 1980s in Brazil was macroeconomic instability and, in particular,

\footnotetext{
32 The sign of the redistribution component in the 1981-2004 decomposition flips across the two poverty lines, suggesting that the manner in which one accounts for differences in the cost-of-living in different regions, and between rural and urban areas, will affect one's interpretations of the impact of falling inequality on poverty. 33 A counterfactual micro-simulation analysis of the 1981-1996 period (in Ferreira and Paes de Barros, 1999) broadly confirms the suggestive evidence from Table 5: changes in the composition of education in the labor force were the main observable force behind rising inequality. Returns to education were falling, and contributing to a decline in inequality. Returns to experience, on the other hand, were rising and contributing to greater inequality. Even in that much more disaggregated - and exclusively urban - analysis, however, an unexplained gap remains for
} 
hyperinflation, one might ask whether these factors can account for some of the unexplained increase in inequality, which shows up in our analysis as increases in "pure dispersion" within the various population subgroups.

High and rising inflation is a particularly plausible culprit. The inflation tax tends to be a regressive wealth tax, since the ability to protect wealth through portfolio adjustments is generally held to be increasing in income, at least over an initial range. In addition, there is some evidence that indexation is not perfect, and that real wages are lower during high-inflation periods (Cardoso, 1992). There is, in fact, considerable support in the literature for the proposition that inflation has distributional consequences, and can lead to higher poverty and inequality. Looking at a reasonably large sample of countries over the 1970-2000 period, Easterly and Fischer (2001) find that inflation is robustly associated with a lower income share for the bottom quintile of the population. ${ }^{34}$ For slightly different cross-country samples, they also find a negative correlation between inflation and minimum wages; and a positive correlation between inflation and poverty incidence. Similar results are obtained by Romer and Romer (1999). A number of single-country studies also find evidence that higher inflation is associated with lower income shares for the poor, including Blejer and Guerrero (1990) for the Philippines; Datt and Ravallion (1998) for India; and Ferreira and Litchfield (2001) for Brazil.

The detailed mechanisms through which higher inflation can lead to increases in inequality (and poverty) are well-discussed by Neri (1995), who lists five channels of impact. In each case, he presents substantial supportive empirical evidence from Brazil. The five channels are: (i) economies of scale in financial transactions: while shoe-leather costs may not vary with the amount involved in a financial transaction aimed at protecting assets from inflation, the benefits do. This would remain the case even if there were no barriers to entry into certain asset markets. (ii) But these barriers to entry are widespread, and restrict access to some assets that are particularly effective in avoiding the inflation tax, to larger depositors. Neri presents revealing evidence about the incidence of ownership of overnight deposits and credit cards across the distribution of income. (iii) Tighter

\footnotetext{
the rise in inequality.

${ }^{34}$ Easterly and Fischer's results suggest that an increase in inflation from zero "to hyperinflation" would decrease the income share of the poorest quintile by 1.7 percentage points (from an average of $6.2 \%$ ). They also study opinion poll responses from some 32.000 households across thirty-eight countries, and find that "inflation aversion" declines with self-reported socio-economic status, even after controlling for education.
} 
labour markets, usually associated with higher skill levels, are better at preserving real salary values. Indexation is less perfect for unskilled, poorer workers. (iv) In addition to financial assets, one can protect the value of one's wealth against inflation by reallocating portfolio from cash to consumption goods. The effectiveness of this strategy declines with the share of goods in one's consumption basket which is perishable, and this is higher for poorer households, due to Engel's law and the fact that a higher share of foodstuffs is perishable than for most other categories of goods. (v) Finally, it also depends on the storage technology available to households. Neri presents evidence on the positive correlation between freezer ownership and household income, which adds another reason why the ability to defend one's wealth against inflation increases with income. ${ }^{35}$

Such inequality-increasing effects of high inflation would be felt predominantly within the partition groupings in Table 5, since their impact on household welfare varies with wealth, rather than any other household attribute. Part of it may be captured in partitions by attributes which are strongly correlated with incomes, such as education. But the bulk of the effect is common to all individuals living in the inflationary environment, and would thus be found in the unexplained component of the dynamic decompositions. The regressive nature of the inflation tax may thus provide a candidate explanation for the large "unexplained component" in changes in inequality during the 1980s. After all, it would be almost surprising if the increase in Brazil's inflation rate from $80 \%$ p.a. in 1980 to $1509 \%$ in 1990 had no distributional effects.

This hypothesis is consistent with the simple correlations one observes between inequality (measured by the Theil index) and (the logarithm of) inflation over the period. Table 7 presents simple correlation coefficients for each of our main sub-periods (1981-1993 and 1993-2004), and both simple and partial correlation coefficients for the period as a whole. ${ }^{36}$ The simple correlation coefficient (of 0.5 ) between inflation and inequality for the whole period is statistically significant

\footnotetext{
35 While the effects of channels (iv) and (v) are not captured by PNAD income data, the first three channels affect capital or labor incomes, and their effects should therefore be registered.

${ }^{36}$ The partial correlation coefficient between two variables $\mathrm{X}$ and $\mathrm{Y}$, holding a third variable Z constant, is given by $r_{X Y \mid Z}=\frac{r_{X Y}-r_{X Z} r_{Y Z}}{\sqrt{\left(1-r_{X Z}^{2}\right)\left(1-r_{Y Z}^{2}\right)}}$, where $\mathrm{r}_{\mathrm{AB}}$ denote the simple correlation coefficient between $\mathrm{A}$ and $\mathrm{B}$.
} 
but, interestingly, this appears to be driven by the strength of the correlation in the hyperinflationary sub-period. ${ }^{37}$ The correlation is both weaker and less significant during 1993-2004.

Table 7 also presents the correlation coefficients between inequality and poverty on the one hand, and an index of real wages in manufacturing in the state of São Paulo on the other. This index is powerfully negatively correlated with the FGT(2) poverty measure in the first period, and with inequality in the second. Like inflation, it is significantly correlated with both poverty and inequality in the entire period. It suggests that the impact of economic growth on poverty is channelled through wage growth in the labor market. ${ }^{38}$

\section{Table 7: Simple and Partial Correlation Coefficients between Distributional and Macroeconomic Variables}

Theil Index

1981-1993

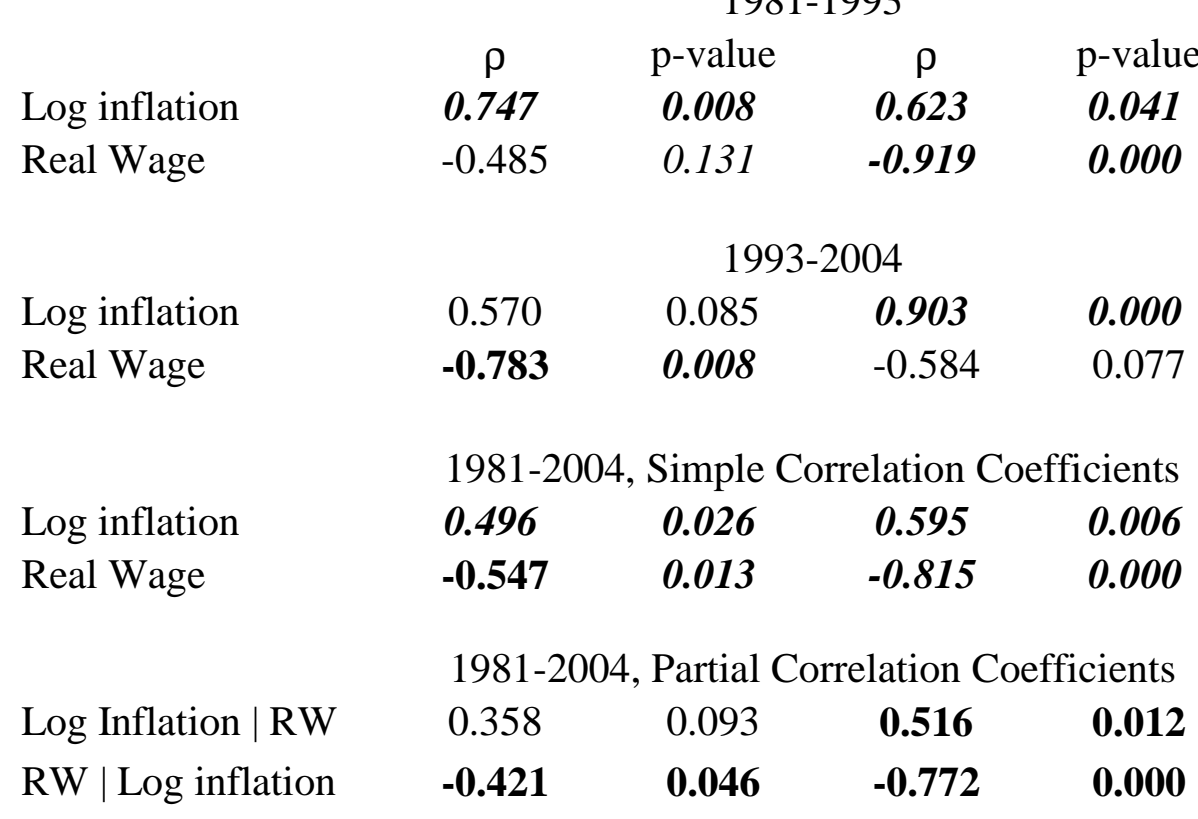

Notes: Values in bold denote coefficients that are statistically significantly different from zero at the $5 \%$ level. RW denotes real wages.

\footnotetext{
37 Urani (1993) and Cardoso et. al. (1995) have also found an impact of inflation on inequality in Brazil during the 1980s.

38 As in Ferreira and Litchfield (2001), we have also looked at the correlation between inequality and poverty on the one hand, and economic growth rates and unemployment rates on the other. The results were not particularly interesting and are omitted here, although they are available on request.
} 
There also appears to be some support for the idea that imperfect indexation (with the real wages of the poor being eroded more rapidly than the incomes of the better-off) is an important part of the inflation story. Whereas the partial correlation of real wages with inequality (given inflation) remains significant, the partial correlation of inequality and inflation (given real wages) is positive, but only significant at $10 \%$. Both corresponding partial correlations remain strong and significant for poverty.

While no inference of causality is made from the correlations described in Table 7, the patterns in the data are consistent with a strong association between rising inflation and rising inequality during the 1980s in Brazil. The patterns are also consistent with the suggestion that this association is mediated by changes in the distribution of real wages, possibly because indexation is imperfect in ways that are not distribution-neutral (Cardoso, 1992; Neri, 1995). The relationship weakens after stabilization in 1994, but it may help account for the residual increments in inequality which were not associated with shifts in the distribution of schooling, or with increasing labor market returns to experience, during the 1980s. The time-series for inflation and inequality are plotted in Figure 3, and those for the real wage index and poverty are plotted in Figure 4.

Figure 3: Inflation and Inequality in Brazil, 1981-2004

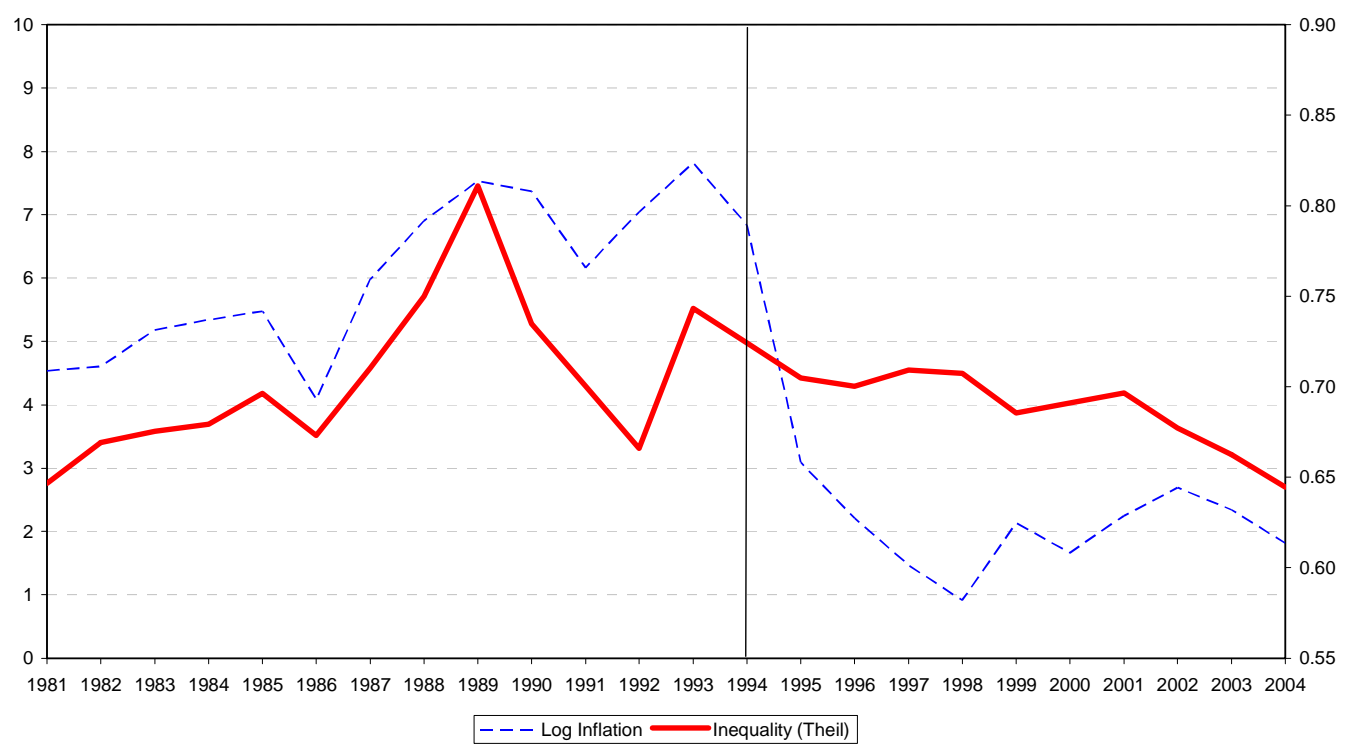




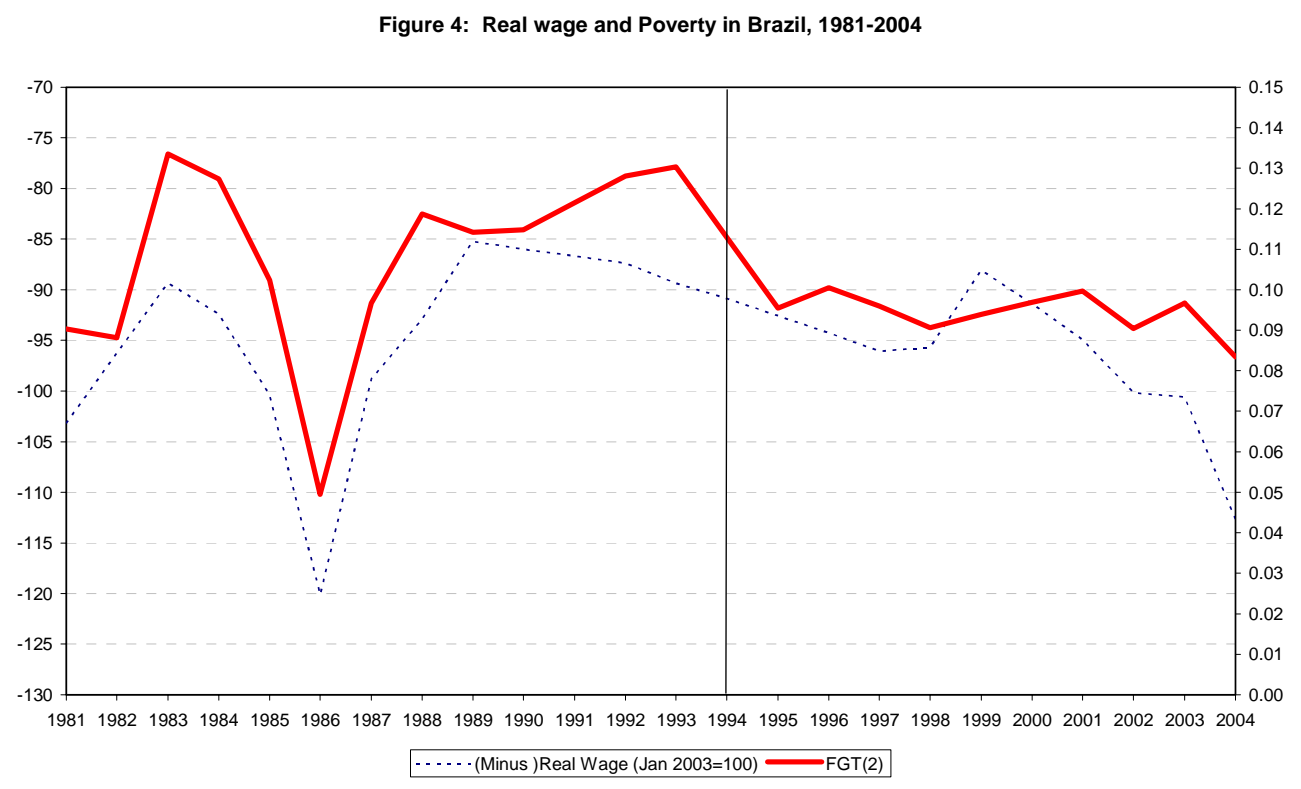

\section{6) Conclusions and More Questions.}

After rising between 1960 and 1976, and declining between 1976 and 1981, Brazilian income inequality resumed its upward trend in 1981. Between 1981 and its peak in 1989, Brazil's Gini coefficient rose by five points (or 9\%) from 0.574 to 0.625 . After oscillating between 1989 and 1993, the Gini then fell to 0.564 in 2004 . The accumulated decline from 1989 to 2004 was of six Gini points or $10 \%$. Similar "inverted-U" patterns are clearly discernible for other inequality measures as well, including the two Theil indices presented in Figure 1. These changes remind us that, while still very high by international standards, Brazil's inequality is not immutable.

Over the same period, poverty also followed a non-linear evolution, rising during the 1982-1983 recession, falling sharply during the mid-80s recovery and the Cruzado year, and then rising again at the end of the decade. Poverty was still higher in 1993, the year which preceded successful economic stabilization, than it had been in 1981. In the ten years following the Real Plan of 1994, poverty fell steadily, by various measures and lines. By the standards of the "administrative poverty line" of R $\$ 100$ per capita per month, incidence fell by ten percentage points, or a third. While most of this decline was driven by Brazil's (modest) economic growth, the decline in inequality observed over the same period also contributed. In fact, inequality reduction during 1993-2004 accounted for 
almost half of the decline in the more bottom-sensitive poverty measures, namely the poverty gap and FGT(2).

In this paper, we have discussed a number of decompositions of levels and changes in both poverty and inequality, in a preliminary investigation of the determinants of Brazil's distributional reversal during the last quarter century. While the decomposition analysis does not allow us to establish the causes of the rise and fall in Brazilian inequality with any certainty, they give rise to a number of interesting candidate explanations.

The rise of inequality from 1981 to 1993 appears to have been associated with two main factors. The first was an expansion in the levels of formal education in the labor force, which led to greater inequality between educational sub-groups of the population. In the dynamic decompositions discussed in this paper, this effect shows up as a composition effect that more than offset the declines in returns to education that were already taking place at that time. A more disaggregated analysis based on counterfactual micro-simulations confirms that the educational expansion was inequality-increasing, due to the convex nature of the returns to schooling in Brazil. ${ }^{39}$ The second candidate explanation was the accelerating rate of inflation, from $80 \%$ p.a. in 1980 to $1509 \%$ in 1990. While the distributional impact of inflation is harder to measure, or even to simulate counterfactually, the correlation between inflation and inequality between 1981 and 1993 is consistent with the various arguments that suggest that inflation is likely to have a regressive impact on the distribution. The evidence is also consistent with at least part of this impact having been mediated through changes in real wages, due to imperfect wage indexation during hyperinflation.

The decline in inequality between 1993 and 2004 is obviously more recent, and has therefore been studied less often, so the hypotheses suggested here are perhaps more tentative. The various decompositions in this paper suggest four candidate explanations: (i) the decline in inequality between educational sub-groups, which appears to be driven by a persistent reduction in the average returns to schooling in Brazil; (ii) although regional convergence (across states) appears to have slowed in the 1990s, income differences between the country's urban and rural areas have fallen dramatically; (iii) a potential decline in racial inequalities; and (iv) increases in the

\footnotetext{
39 See Ferreira and Paes de Barros (1999). They also find that an increase in the returns to experience and an increase in unemployment over this period contributed to growing inequality. These factors more than outweighed an
} 
volume and improvements in the targeting of social assistance transfers from the government. Naturally, economic stability and the demise of hyper-inflation, which do not appear in the analysis for the 1990s directly, have helped by omission: the absence of a force that contributed to rising inequality in the past has helped its recent decline.

The analysis in this paper does not permit a quantification of the relative importance of these different potential explanations. In some cases, notably the reduction in racial inequality, we can not even be sure that the effect is not spurious. In at least one other case, we have not even considered a potential candidate explanation that does deserve attention, namely the real increases in minimum wages since 1994. Could we be observing in Brazil the opposite trend to the one that DiNardo et. al. (1996) found for the United States, where falling real minimum wages appeared to account for some of the increase in wage inequality between 1979 and 1988 ? In all cases, further research is needed, both to isolate the partial contribution of each effect, and to ascertain their relative importance.

Going further, one would also like to understand the economic processes behind each of these factors. While this is relatively straight-forward in the case of greater and better-targeted transfers (candidate explanation $i v$ ), the determinants of $(i)$ and $(i i)$ are far from obvious. What lies behind Brazil's remarkable rural-urban convergence over the last two decades? Is it the growth of the modern agricultural export sector, ignited perhaps by the trade liberalization of the early 1990s, and supported thereafter by high international commodity prices? Is it greater access to land among small-holders, including those who have benefited from the ongoing land-reform initiatives? Is it the growth in off-farm employment opportunities, as discussed in Ferreira and Lanjouw (2001)? Or is it the expansion in minimum pensions to agricultural workers during the 1990s, under the Previdência Rural and the Lei Orgânica de Assistência Social (LOAS) ${ }^{40}$ The lessons from the process of urban-rural convergence which we have observed for future policymaking clearly depend on the relative contributions of these various phenomena.

One can similarly ask: what is behind the decline in returns to education in Brazil? Is this process still confined to returns to secondary schooling, or have returns to tertiary schooling started 
falling too? Has supply outpaced demand across the distribution of skills? If so, does this reflect mostly a success of education policy, or a failure to produce and adopt skill-intensive technologies across the economy? Why does Brazil seem to see so little evidence of skill-biased technical change?

Like many other descriptive papers, our analysis of the rise and fall of Brazilian inequality in the last two and a half decades appears to have generated more questions than answers. We hope future work can shed some light on them. 


\section{References.}

Ahuja, V., B. Bidani, F. H. G. Ferreira and M. Walton (1997): Everyone's Miracle?: Revisiting Poverty and Inequality in East Asia (Washington, DC: The World Bank).

Amadeo, E. and J. M. Camargo (1997): "Brazil: Regulation and Flexibility in the Labor Market" in S. Edwards and N. Lustig (eds.) Labor Markets in Latin America (Washington, DC: The Brookings Institution).

Azzoni, C. (1994): "Crescimento Econômico e Convergência das Rendas Regionais: o caso brasileiro", Anais do XXII Encontro Nacional de Economia (ANPEC), 1, pp.185-205.

Barros, R. P., R. Henriques and R. Mendonça (2000): “A Estabilidade Inaceitável: desigualdade e pobreza no Brasil”, Ch. 1 in R. Henriques (ed.) Desigualdade e Pobreza no Brasil (Rio de Janeiro, IPEA).

Blejer, M. and I. Guerrero (1990): "The Impact of Macroeconomic Policies on Income Distribution: An Empirical Study of the Philippines", Review of Economics and Statistics, LXXII (3), pp.414-423.

Bonelli, R and G. L. Sedlacek (1989): "Distribuição de Renda: evolução no último quarto de século", in Sedlacek, G. L. and R. Paes de Barros, Mercado de Trabalho e Distribuição de Renda: Uma Coletânea, (Rio de Janeiro: IPEA; Série Monográfica \#35).

Bourguignon, F. (1979): "Decomposable Income Inequality Measures", Econometrica, 47, pp.90120.

Bourguignon, F., F.H.G. Ferreira and N. Lustig (2005): The Microeconomics of Income Distribution Dynamics in East Asia and Latin America (Washington DC: The World Bank and Oxford University Press).

Cardoso, E. (1992): "Inflation and Poverty", NBER Working Paper No. 4006 (Cambridge, MA).

Cardoso, E., R. Paes de Barros and A. Urani (1995): "Inflation and Unemployment as Determinants of Inequality in Brazil: the 1980s", Chapter 5 in Dornbusch, R. and Edwards, S. (eds): Reform, Recovery and Growth: Latin America and the Middle-East; (Chicago: University of Chicago Press for the NBER).

Corseuil, C.H.L. and M.N. Foguel (2002): "Uma Sugestão de Deflatores para Rendas Obtidas a partir de Algumas Pesquisas Domiciliares do IBGE", IPEA Texto para Discussão \#897, Rio de Janeiro.

Cowell, F.A. (1980): "On the Structure of Additive Inequality Measures", Review of Economic Studies, 47, pp.521-31. 
Cowell, F.A. (1995): Measuring Inequality, 2nd edition, (Hemel Hempstead: Harvester Wheatsheaf).

Cowell, F.A. and S.P. Jenkins (1995): "How much inequality can we explain? A methodology and an application to the USA", Economic Journal, 105, pp.421-430.

Datt, G., and M. Ravallion (1992): "Growth and Redistribution Components of Changes in Poverty Measures: A Decomposition with Applications to Brazil and India in the 1980s." Journal of Development Economics, 38 (2), pp.275-95.

Datt, G. and M. Ravallion (1998): "Farm Productivity and Rural Poverty in India", Journal of Development Studies, 34, pp.62-85.

De Ferranti, D., G. Perry, F. H. G. Ferreira and M. Walton (2004): Inequality in Latin America?: Breaking with History? (Washington, DC: The World Bank).

Delgado, G and J.C. Cardoso Jr. (2000): A Universalização de Direitos Sociais no Brasil: a Previdência Rural nos Anos 90, (Brasília: IPEA).

DiNardo, J., N. Fortin and T. Lemieux (1996): "Labor Market Institutions and the Distribution of Wages, 1973-1992: A Semi-Parametric Approach”, Econometrica, 64 (5), pp.1001-1044.

Easterly, W. and S. Fischer (2001): "Inflation and the Poor", Journal of Money, Credit and Banking, 33 (2), pp.160-178.

Ellery Jr., R. and P.C. Ferreira (1994): "Crescimento Econômico e Convergência entre as Rendas dos Estados Brasileiros", Anais do XVI Encontro Brasileiro de Econometria (SBE), pp.264-286.

Fava, V.L. (1984): "Urbanização, Custo de Vida e Pobreza no Brasil", Instituto de Pesquisa Economica Aplicada (Rio de Janeiro)/ University of São Paulo, mimeo.

Ferreira, A. (2000): "Convergence in Brazil: recent trends and long-run prospects", Applied Economics, 32, pp.479-489.

Ferreira, F.H.G. and P. Lanjouw (2001): "Rural Nonfarm Activities and Poverty in the Brazilian Northeast", World Development, 29, 3, pp.509-528.

Ferreira, F.H.G., P. Lanjouw and M.C. Neri (2003): “A Robust Poverty Profile for Brazil using Multiple Data Sources", Revista Brasileira de Economia, 57 (1), pp.59-92.

Ferreira, F.H.G. and J.A. Litchfield (2000): "Desigualdade, Pobreza e Bem-Estar Social no Brasil: 1981/95", Ch. 2 in R. Henriques (ed.): Desigualdade e Pobreza no Brasil (Rio de Janeiro, IPEA). 
Ferreira, F.H.G. and J.A. Litchfield (2001): "Education or Inflation?: The Micro and Macroeconomics of the Brazilian Income Distribution during 1981-1995”, Cuadernos de Economía, 38 (141), pp.209-238.

Ferreira, F.H.G. and R. Paes de Barros (1999): "The Slippery Slope: Explaining the Increase in Extreme Poverty in Urban Brazil, 1976-1996”, Brazilian Review of Econometrics, 19 (2), pp.211-296.

Foster, J., J. Greer, and E. Thorbecke, 1984, “A class of decomposable poverty measures.” Econometrica, 52, pp.761-65.

Hoffman, R. (1989): "Evolução da Distribuição da Renda no Brasil, Entre Pessoas e Entre Famílias, 1979/86", in Sedlacek, G.L. and R. P. de Barros (eds.) Mercado de Trabalho e Distribuição de Renda: Uma Coletânea (Rio de Janeiro: IPEA, Série Monográfica No. $35)$.

Instituto Brasileiro de Geografia e Estatística (IBGE) (1993): Pesquisa Nacional por Amostra de Domicílios: Síntese de Indicadores da Pesquisa Básica - 1990, (Rio de Janeiro: IBGE).

Jenkins, S.P. (1995): "Accounting for Inequality Trends: Decomposition Analyses for the UK, 1971-86",_Economica, 62, pp.29-63.

Lara Resende, A., D. Funaro, J. Sayad, L. G. Belluzzo, P. Arida and A. Solnik (1987): Por Que Não Deu Certo (São Paulo: L\&PM Editores).

Leme, M.C.S. And S. Wajnman (2001): "Diferenciais de Rendimento por Gênero" in M.B. Lisboa and N.A. Menezes-Filho (eds.) Microeconomia e Sociedade no Brasil (Rio de Janeiro: Contra-Capa Livraria).

Litchfield, J.A. (2001): Welfare and Income Distribution in Brazil, 1981-1995, Ph.D. Dissertation, London School of Economics.

Mookherjee, D. and A. Shorrocks (1982): "A Decomposition Analysis of the Trend in UK Income Inequality", Economic Journal, 92, pp.886-902.

Neri, M. (1995): "Sobre a Mensuração dos Salários Reais em Alta Inflação", Pesquisa $e$ Planejamento Econômico, 25, no. 3, pp.497-525.

Ramos, L. (1993): A Distribuição de Rendimentos no Brasil: 1976/85, (IPEA: Rio de Janeiro).

Rocha, S. (1993): "Poverty Lines for Brazil: New Estimates from Recent Empirical Evidence", IPEA - Rio de Janeiro, mimeo.

Romer, C.D. and D.H. Romer (1999): "Monetary Policy and the Well-Being of the Poor", Federal Reserve Bank of Kansas City Economic Review, First Quarter, pp.21-49. 
Shorrocks, A.F. (1980): "The Class of Additively Decomposable Inequality Measures", Econometrica, 48, pp.613-25.

Shorrocks, A.F. (1982): "Inequality decomposition by Factor Components" Econometrica, 50(1), pp.193-211.

Shorrocks, A.F. (1984): "Inequality Decomposition by Population Subgroup", Econometrica, 52, pp.1369-85.

Tanner, C. (1987): "Malnutrition and the Development of Rural Households in the Agreste of Paraíba State, North-East Brazil”, Journal of Development Studies, 23, 2.

Urani, A. (1993): "Inflação e Desemprego como Determinantes do Nível e da Distribuição da Renda do Trabalho no Brasil Metropolitano; 1982-1992", IPEA Série Seminários no. 04/93, Rio de Janeiro.

World Bank (2005): World Development Report 2006: Equity and Development (Washington, D.C: The World Bank and Oxford University Press) 
Appendix 1: INPC Temporal

Price Deflator, 1981-2004.

\begin{tabular}{|cc|}
\hline Year & September $2004=1$ \\
\hline 1979 & 7.430 \\
1980 & 13.821 \\
1981 & 27.760 \\
1982 & 54.338 \\
1983 & 144.115 \\
1984 & 415.808 \\
1985 & 1311.211 \\
1986 & 2.611 \\
1987 & 10.454 \\
1988 & 84.815 \\
1989 & 1.172 \\
1990 & 34.729 \\
1991 & 171.284 \\
1992 & 2138.101 \\
1993 & 44.534 \\
1994 & 0.422 \\
1995 & 0.526 \\
1996 & 0.589 \\
1997 & 0.605 \\
1998 & 0.626 \\
1999 & 0.658 \\
2000 & 0.700 \\
2001 & 0.753 \\
2002 & 0.821 \\
2003 & 0.942 \\
2004 & 1 \\
2005 & 1.047 \\
\hline 504. & \\
\hline
\end{tabular}

Source: Índice Nacional de Preços ao

Consumidor (INPC); Instituto Brasileiro de Geografia e Estatística

Note: The Corseuil and Fogel (2002)

adjustment to the 1994 IBGE INPC index is applied. 
Appendix 2: Sônia Rocha's (1993) Spatially Disaggregated Per Capita Poverty Lines

\begin{tabular}{|c|c|c|}
\hline \multicolumn{2}{|c|}{ PNAD Regions } & \multirow{2}{*}{$\begin{array}{c}\text { Value (in Sept. 2004 Reais) } \\
234.59\end{array}$} \\
\hline Region I & Metropolis of Rio de Janeiro & \\
\hline & Urban & 145.44 \\
\hline & Rural & 105.57 \\
\hline \multirow[t]{3}{*}{ Region II } & Metropolis of Sao Paulo & 249.96 \\
\hline & Urban & 157.48 \\
\hline & Rural & 99.98 \\
\hline \multirow[t]{4}{*}{ Region III } & Metropolis of Curitiba & 200.91 \\
\hline & Metropolis of Porto Alegre & 139.48 \\
\hline & Urban & 127.65 \\
\hline & Rural & 85.10 \\
\hline \multirow[t]{3}{*}{ Region IV } & Metropolis of Belo Horizonte & 192.79 \\
\hline & Urban & 129.16 \\
\hline & Rural & 75.18 \\
\hline \multirow[t]{5}{*}{ Region V } & Metropolis of Fortaleza & 146.58 \\
\hline & Metropolis of Recife & 195.14 \\
\hline & Metropolis of Salvador & 224.02 \\
\hline & Urban & 132.00 \\
\hline & Rural & 79.21 \\
\hline Region VI & Brasilia & 239.83 \\
\hline \multirow[t]{3}{*}{ Region VII } & Metropolis of Belem & 135.91 \\
\hline & Urban & 120.96 \\
\hline & Rural $^{1}$ & 89.01 \\
\hline \multirow[t]{3}{*}{ Region VIII } & Goiania & 227.91 \\
\hline & Urban & 173.20 \\
\hline & Rural $^{1}$ & 89.01 \\
\hline
\end{tabular}

Note: ${ }^{1}$ The rural poverty line in Regions VII and VIII is the unweighted average of all other rural poverty lines.

Source: Table XIII in Rocha (1993), inflated to 2004 R \$ using the INPC deflator in Appendix 1. 
Appendix 3: A comparison of Gini Coefficients and E(2) for the distributions excluding and including households with zero total incomes

\begin{tabular}{cccccc}
\hline Year & $\begin{array}{c}\text { Population share } \\
\text { of households with } \\
\text { zero incomes in } \\
\text { the sample }\end{array}$ & $\begin{array}{c}\text { Gini } \\
\text { (excluding } \\
\text { zero incomes) }\end{array}$ & $\begin{array}{c}\text { Gini } \\
\text { (including } \\
\text { zero incomes) }\end{array}$ & $\begin{array}{c}\text { E (2) } \\
\text { (excluding zero } \\
\text { incomes) }\end{array}$ & $\begin{array}{c}\text { E (2) (including } \\
\text { zero incomes) }\end{array}$ \\
$\mathbf{1 9 8 1}$ & $0.9 \%$ & 0.574 & 0.577 & 1.447 & 1.461 \\
$\mathbf{1 9 8 2}$ & $0.9 \%$ & 0.581 & 0.584 & 1.552 & 1.566 \\
$\mathbf{1 9 8 3}$ & $1.1 \%$ & 0.584 & 0.587 & 1.515 & 1.534 \\
$\mathbf{1 9 8 4}$ & $0.9 \%$ & 0.583 & 0.586 & 1.464 & 1.477 \\
$\mathbf{1 9 8 5}$ & $0.5 \%$ & 0.589 & 0.591 & 1.622 & 1.631 \\
$\mathbf{1 9 8 6}$ & $0.5 \%$ & 0.578 & 0.580 & 1.637 & 1.645 \\
$\mathbf{1 9 8 7}$ & $0.7 \%$ & 0.592 & 0.594 & 1.791 & 1.803 \\
$\mathbf{1 9 8 8}$ & $0.7 \%$ & 0.609 & 0.611 & 1.742 & 1.752 \\
$\mathbf{1 9 8 9}$ & $0.7 \%$ & 0.625 & 0.627 & 2.212 & 2.225 \\
$\mathbf{1 9 9 0}$ & $1.0 \%$ & 0.604 & 0.607 & 1.767 & 1.786 \\
$\mathbf{1 9 9 2}$ & $1.5 \%$ & 0.573 & 0.578 & 1.876 & 1.905 \\
$\mathbf{1 9 9 3}$ & $1.3 \%$ & 0.595 & 0.600 & 2.308 & 2.337 \\
$\mathbf{1 9 9 5}$ & $1.4 \%$ & 0.591 & 0.596 & 1.627 & 1.654 \\
$\mathbf{1 9 9 6}$ & $2.0 \%$ & 0.591 & 0.598 & 1.609 & 1.645 \\
$\mathbf{1 9 9 7}$ & $1.7 \%$ & 0.593 & 0.598 & 1.739 & 1.771 \\
$\mathbf{1 9 9 8}$ & $1.6 \%$ & 0.591 & 0.597 & 1.672 & 1.701 \\
$\mathbf{1 9 9 9}$ & $1.5 \%$ & 0.585 & 0.590 & 1.530 & 1.556 \\
$\mathbf{2 0 0 1}$ & $1.8 \%$ & 0.586 & 0.592 & 1.661 & 1.696 \\
$\mathbf{2 0 0 2}$ & $1.4 \%$ & 0.580 & 0.585 & 1.522 & 1.545 \\
$\mathbf{2 0 0 3}$ & $1.6 \%$ & 0.575 & 0.580 & 1.474 & 1.498 \\
$\mathbf{2 0 0 4}$ & $1.2 \%$ & 0.564 & 0.568 & 1.618 & 1.638 \\
Source: Authors' calculations from the PNADs. & & & \\
\hline & & & & & \\
\hline
\end{tabular}

